Mineralogy and Geology of

the Wagnerite Occurrence

on Santa Fe Mountain,

Front Range, Colorado

GEOLOGICALSURVEY PROFESSIONAL PAPER 955

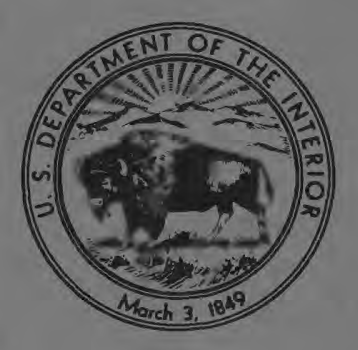




\section{Mineralogy and Geology of}

the Wagnerite Occurance

on Santa Fe Mountain,

Front Range, Colorado

By DOUGLAS M. SHERIDAN, SHERMAN P. MARSH, MARY E. MROSE, and RICHARD B. TAYLOR

GEOLOGICAL SURVEY PROFESSIONAL PAPER 955

A detailed mineralogic study of wagnerite, a rare phosphate mineral occurring in the report area in Precambrian gneiss; this is the first recorded occurrence of wagnerite in the United States

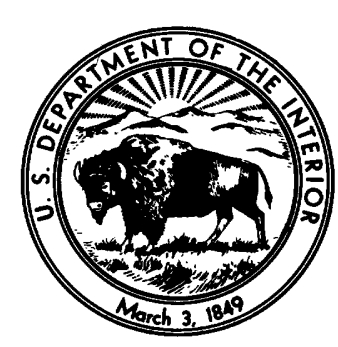




\section{UNITED STATES DEPARTMENT OF THE INTERIOR}

THOMAS S. KLEPPE, Secretary

\section{GEOLOGICAL SURVEY}

V. E. McKelvey, Director

Library of Congress Cataloging in Publication Data

Main entry under title:

Mineralogy and geology of the wagnerite occurrence on Santa Fe Mountain, Front Range, Colorado.

(Geological Survey Professional Paper 955)

Includes bibliographical references.

1. Wagnerite-Colorado-Santa Fe Mountain. 2. Geology-Colorado-Santa Fe Mountain.

I. Sheridan, Douglas M., 1921- II. Series: United States Geological Survey Professional Paper 955.

QE391.W3M 56 549'.72 76-10335

For sale by the Superintendent of Documents, U.S. Government Printing Office Washington, D.C. 20402

Stock Number 024-001-02844-1 


\section{CONTENTS}

Metric-English equivalents

Abstract

Introduction

Acknowledgments

Geologic setting.

Occurrence ......

Descriptive mineralogy

Methods used for optical determinations.
Descriptive mineralogy-Continued

Wagnerite.

Mineral assemblages and textural relations

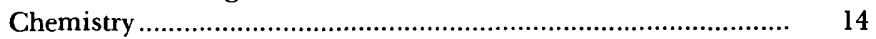

X-ray crystallography ........................................................ 15

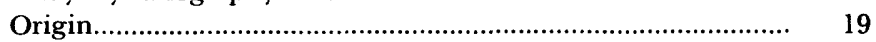

References cited.................................................................. 22

\section{ILLUSTRATIONS}

FIGURE 1. Map of east-central Front Range showing Santa Fe Mountain wagnerite locality and location of figure 2...

2. Map showing distribution of rutile-bearing light-colored gneisses in the Santa Fe Mountain-Beaver Brook-Soda

Creek area.

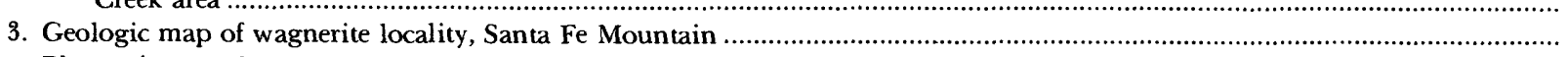
Photomicrographs:

4. Large ameboid-shaped grain of wagnerite.

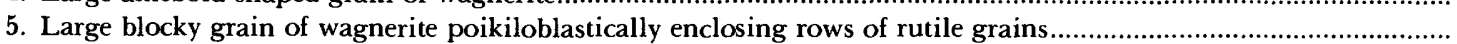

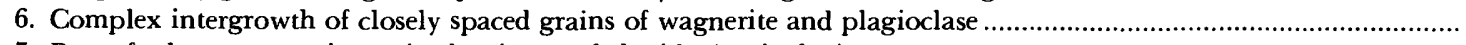

7. Part of a large wagnerite grain that is crowded with tiny inclusions

8, 9. Rims of apatite on wagnerite.

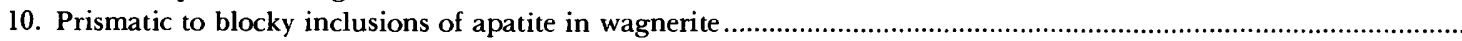

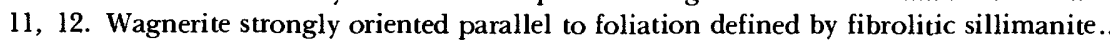

13, 14. Prismatic sillimanite cutting wagnerite and other minerals.

15. Corundum containing numerous needles of sillimanite...

16. Corundum and rutile along grain boundaries of wagnerite.

17. X-ray powder photographs of wagnerite, ferroan wagnerite,

\section{TABLES}

TABLE 1. Modes of light-colored gneisses, Santa Fe Mountain wagnerite locality, Colorado

2. Optical data for wagnerite from Santa Fe Mountain, Colorado.

3. Comparison of optical data for wagnerite.

4. Optical data for other minerals from wagnerite locality, Santa Fe Mountain, Colorado.

5. Chemical analyses of wagnerite

6. Microprobe analysis of wagnerite from Santa Fe Mountain, Colorado.

7. Crystallographic, compositional, and density data compared for wagnerite, ferroan wagnerite, magniotriplite, and triplite.

8. X-ray powder diffraction data for wagnerite, $\mathrm{Mg}_{2}\left(\mathrm{PO}_{4}\right) \mathrm{F}$ 


\section{METRIC-ENGLISH EQUIVALENTS}

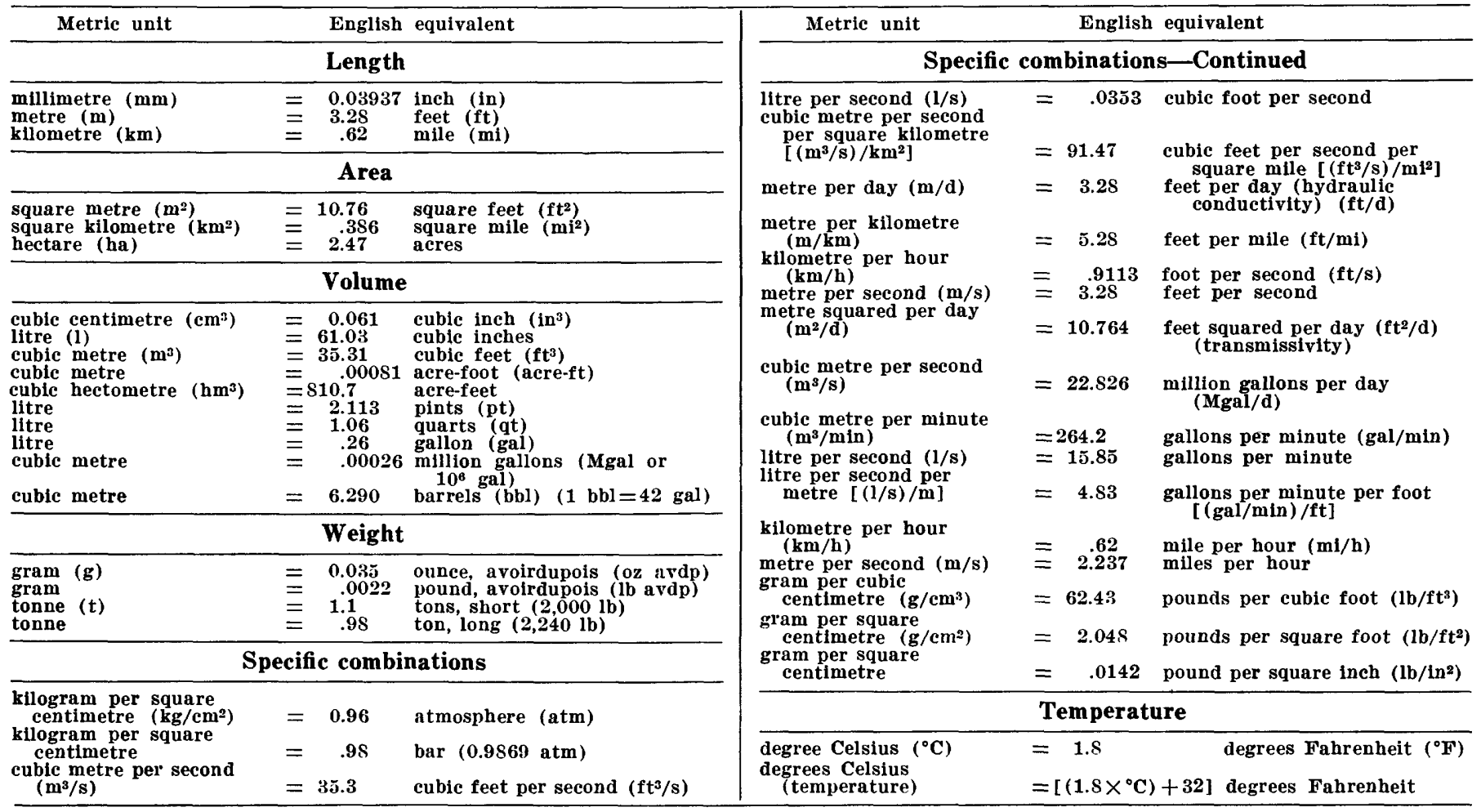




\title{
MINERALOGY AND GEOLOGY OF THE WAGNERITE OCCURRENCE ON SANTA FE MOUNTAIN, FRONT RANGE, COLORADO
}

\author{
By Douglas M. Sheridan, Sherman P. Marsh, \\ Mary E. Mrose, and Richard B. TAylor
}

\begin{abstract}
The first known occurrence in the United States of wagnerite, a rare magnesium fluophasphate, is on Santa Fe Mountain near Idaho Springs in the Colorado Front Range. Wagnerite occurs as a minor constituent of thin lenses of sillimanite-plagioclase gneiss of Precambrian age. Other minerals in the gneiss are corundum, rutile, pale-brown biotite, apatite, monazite, zircon, and tourmaline. The sillimanite-plagioclase gneiss is a local lithologic variant of a persistent layer of rutile-bearing sillimanitequartz gneiss and related rocks that has been traced $13 \mathrm{~km}$ along a Z shaped fold southeastward from the northern flank of Santa Fe Mountain.
\end{abstract}

The wagnerite from Santa Fe Mountain is anhedral, mostly fine grained, and pale yellow to yellowish tan. Luster is vitreous to slightly resinous. Cleavage (100) is very poor. In transmitted light, grains are colorless and nonpleochroic. The indices of refraction and the optic angle show a range in values: $\alpha=1.565-1.571, \beta=1.567-1.572$, $\gamma=1.578-1.585$ (all \pm 0.002 ); $(+) 2 V=28^{\circ}-33^{\circ}\left( \pm 1^{\circ}\right)$. Dispersion is $r>v$, weak.

Textural relations indicate that a single stable mineral assemblage characterizes the sillimanite-plagioclase gneiss: wagnerite+plagioclase (albite)+fibrolitic sillimanite+magnesian biotite. To this assemblage may be added small amounts of rutile, monazite, zircon, and apatite, minerals inferred to represent phases belonging to a relatively early stage of crystallization during high-grade regional metamorphism. Corundum, prismatic sillimanite, and some apatite crystallized later but probably during the same regional metamorphism.

Chemical analysis of the wagnerite from Santa Fe Mountain led to the formula $(\mathrm{Mg}, \mathrm{Fe}, \mathrm{Mn})_{2.03} \mathrm{PO}_{4}(\mathrm{~F}, \mathrm{Cl})_{0.96}$, with $\mathrm{Mg}: \mathrm{Fe}: \mathrm{Mn}=$ $0.97: 0.02: 0.01$; this formula is close to the empirical formula $\mathrm{Mg}_{2}\left(\mathrm{PO}_{4}\right) \mathrm{F}$.

Single crystal X-ray-diffraction studies showed that the wagnerite from Santa Fe Mountain is monoclinic, space group $P 2_{1} / a$, with $a=11.9263 \pm 0.0007 \quad \mathrm{~A}, \quad b=12.6707 \pm 0.0008 \quad \mathrm{~A}, \quad c=9.6411 \pm 0.0005 \quad \mathrm{~A}$, $\beta=108.283^{\circ} \pm 0.005^{\circ}$, volume $=1,383.37 \mathrm{~A}^{3}$. Specific gravity calculated from refined cell data is $3.16 \mathrm{~g} / \mathrm{cc}$; specific gravity measured by the pycnometer method is $3.13 \mathrm{~g} / \mathrm{cc}$. A strong monoclinic subcell is present with the $b$-axis halved ( $6.335 \mathrm{~A}$ ); the subcell is in space group $12 / a$ with $Z=8$, and its cell parameters are comparable with those reported in the literature for triplite-group minerals. The X-ray powder-diffraction pattern taken in $\mathrm{Fe} / \mathrm{Mn}$ radiation has the following strong lines ( $h k l, d$, I): $\overline{1} 41,2.970 \mathrm{~A}(100) ; \overline{4} 02,2.839 \mathrm{~A}(85) ; 202,3.114 \mathrm{~A}(60) ; 122,3.287 \mathrm{~A}$ (60); 023, 2.748 A (30); $421,2.697$ A (21).

A comparison of crystallographic data for wagnerite, ferroan wagnerite, magniotriplite, and triplite indicates that, despite their high magnesium content, ferroan wagnerite and magniotriplite are members of the triplite group and have a true cell that is different from that of wagnerite. So-called "ferroan wagnerite," from Hållsjöberget, Sweden, and from the Albères massif, eastern Pyrenees, France, is actually magniotriplite; this material should not be referred to as ferroan wagnerite. Although X-ray powder-diffraction patterns of ferroan wagnerite and magniotriplite resemble the diffraction pattern of wagnerite, the pattern for wagnerite has a line at $5.66 \mathrm{~A}$ which distinguishes it from triplite-group minerals.

Rutile-bearing gneisses in the east-central Front Range are believed to have formed by metamorphism of bentonitic clays that were generated during intense weathering of intermediate to basic tuffs and flows in Precambrian time. The clays were partly reworked by surface waters; fluorine of probable volcanic source was adsorbed locally. After a thick succession of interlayered volcanic and sedimentary rocks accumulated, high-grade regional metamorphism took place. The thin layers and lenses of reworked weathered materials recrystallized to form rutilebearing sillimanite-quartz gneiss and related feldspathic rocks. Wagnerite formed locally, instead of apatite, where the amount of calcium was insufficient to accommodate the available phosphate.

\section{INTRODUCTION}

Wagnerite, a rare magnesium fluophasphate mineral, occurs as a minor constituent of thin layers of rutilebearing gneiss in regionally metamorphosed rocks of Precambrian age on the northern flank of Santa Fe Mountain, $3.5 \mathrm{~km}$ southeast of Idaho Springs in the east-central Front Range, Clear Creek County, Colorado (fig. 1). This is the first recorded occurrence of wagnerite in the United States (Sheridan and others, 1971).

Sheridan and Marsh examined the Santa Fe Mountain area in 1968 during field investigation of rutile-bearing. gneisses in this region. Petrographic studies of rock samples from this area subsequently disclosed the presence of an unknown biaxial positive mineral that has a small optic angle. Optical, X-ray, and chemical investigations proved this mineral to be wagnerite. Additional samples were obtained by Sheridan and Marsh in 1969 and a geologic map of the wagnerite locality was prepared (fig. 3).

This report describes the occurrence and properties of wagnerite from Santa Fe Mountain, Colo. Also included are descriptions of other minerals and the mineral assemblages, a comparison of the optical, chemical, and X-ray data for Colorado wagnerite with data for wagnerite from other localities in the world, and a discussion of 


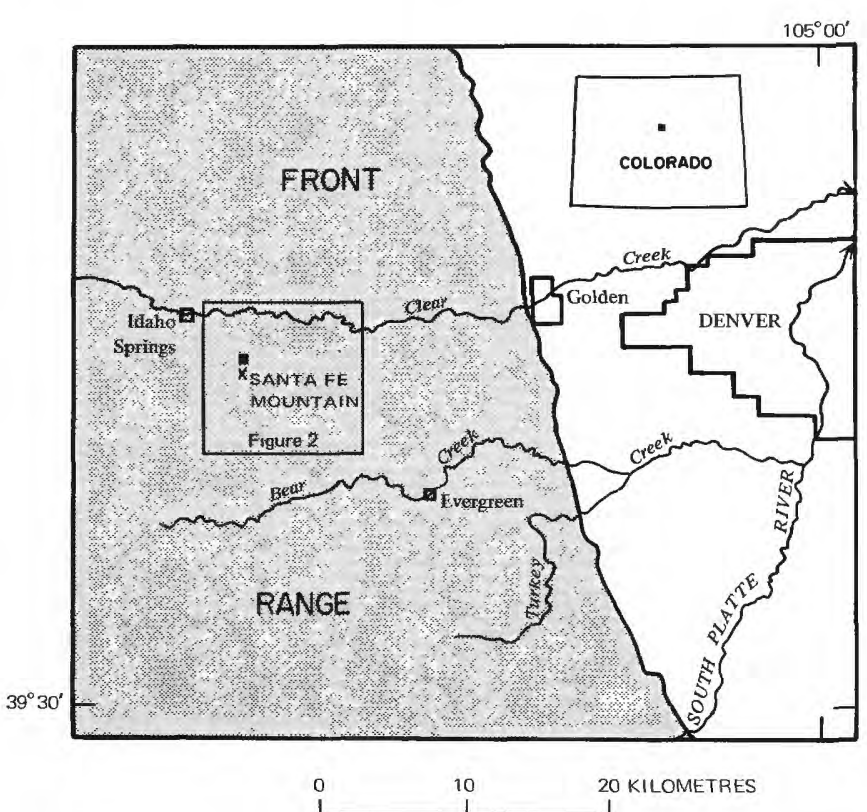

Figure 1.-Map of east-central Front Range showing Santa Fe Mountain wagnerite locality (black square) and location of figure 2 .

origin of the Colorado wagnerite. Responsibilities and credits are: Sheridan and Marsh provided the geologic field data and, together with Taylor, determined the descriptive mineralogy, petrography, and mineral assemblages; Mrose provided detailed X-ray data, discussions of the chemistry and X-ray crystallography, and comparison of wagnerite with ferroan wagnerite, magniotriplite, and triplite.

\section{ACKNOWLEDGMENTS}

We wish to thank Cabins, Inc. of Wheatridge, Colo., for its cooperation in permitting us to sample and study this wagnerite occurrence on their property. It is pertinent to mention that although wagnerite is a rare mineral, neither the wagnerite nor the corundum, which also occurs at this locality, can be regarded as having special museum or specimen value. These minerals are minor constituents of a metamorphic rock and, as such, are important to the geologist as unusual mineral phases in an uncommon metamorphic assemblage rather than to a mineral collector.

We are grateful to numerous U.S. Geological Survey colleagues for their help during this study. John W. Adams, George A. Desborough, Fred A. Hildebrand, and James M. Nishi made microchemical and other tests during the early part of the investigation. Laura $\mathrm{E}$. Reichen provided the quantitative chemical analysis, Johnnie Gardner provided a fluorine determination, and Robert B. Finkelman made a microprobe analysis. Ray E. Wilcox, Irving J. Witkind, and Glenn A. Izett gave helpful advice during petrographic determinations of optical data. Judith Konnert calculated the powder pattern for wagnerite from near Werfen, Austria, and also carried out least-squares analysis of the Colorado wagnerite.

All specimens used in these investigations, except those from the Colorado locality, were kindly supplied by several individuals: ferroan wagnerite from eastern Pyrenees by François Fontan of the Laboratoire de Minéralogie-Cristallographie (Toulouse, France); type magniotriplite, by Dr. Prof. G. Barsanov of the Fersman Mineralogical Museum (Leningrad, U.S.S.R.); and all other study materials, by Paul Desautels of the U.S. National Museum (Washington, D. C.).

\section{GEOLOGIC SETTING}

The wagnerite locality lies in the east-central part of the block of uplifted Precambrian rocks that form the core of the Colorado Front Range. Bedrock in the general vicinity of the occurrence is composed of a thick folded succession of gneisses of high metamorphic grade. These interlayered metasedimentary and metavolcanic rocks contain mineral assemblages in general correlative with the sillimanite zone and the upper part of the amphibolite facies. The regional metamorphism accompanied a long Precambrian period of deformation that involved two stages of plastic folding. Tight to open west-northwest-trending folds were formed first and, in some areas, were modified subsequently by more northerly trending crossfolds. Although granitic plutons were emplaced in this general region during three major periods of igneous activity in the Precambrian Era, the closest major igneous bodies are more than $5 \mathrm{~km}$ from the wagnerite locality. The geologic setting, therefore, is regional metamorphic rather than contact metamorphic.

Feldspar-rich gneiss (chiefly plagioclase, quartz, microcline, and biotite) and biotite gneiss (chiefly biotite, plagioclase, and quartz) are the principal metamorphic rocks in the east-central Front Range. Much of the biotite gneiss is sillimanitic, and some contains garnet-bearing and cordierite-bearing layers. Interlayered with the feldspar-rich gneiss and the biotite gneiss are variable amounts of hornblende gneiss, amphibolite, and calcsilicate gneiss.

Thin layers and lenses of rutile-bearing light-colored gneisses occur at several stratigraphic levels within this thick succession of gneisses. These range in thickness from $15 \mathrm{~cm}$ to $30 \mathrm{~m}$ and contain from trace amounts to about 5 percent of rutile. A remarkably persistent layer has been traced along a $Z$-shaped fold for about $13 \mathrm{~km}$ southeastward from the northern flank of Santa Fe Mountain (fig. 2). The distribution of the rutile-bearing gneisses and other Precambrian rocks in the east-central Front Range is shown in a generalized map by Marsh and Sheridan (1976, fig. 2). 


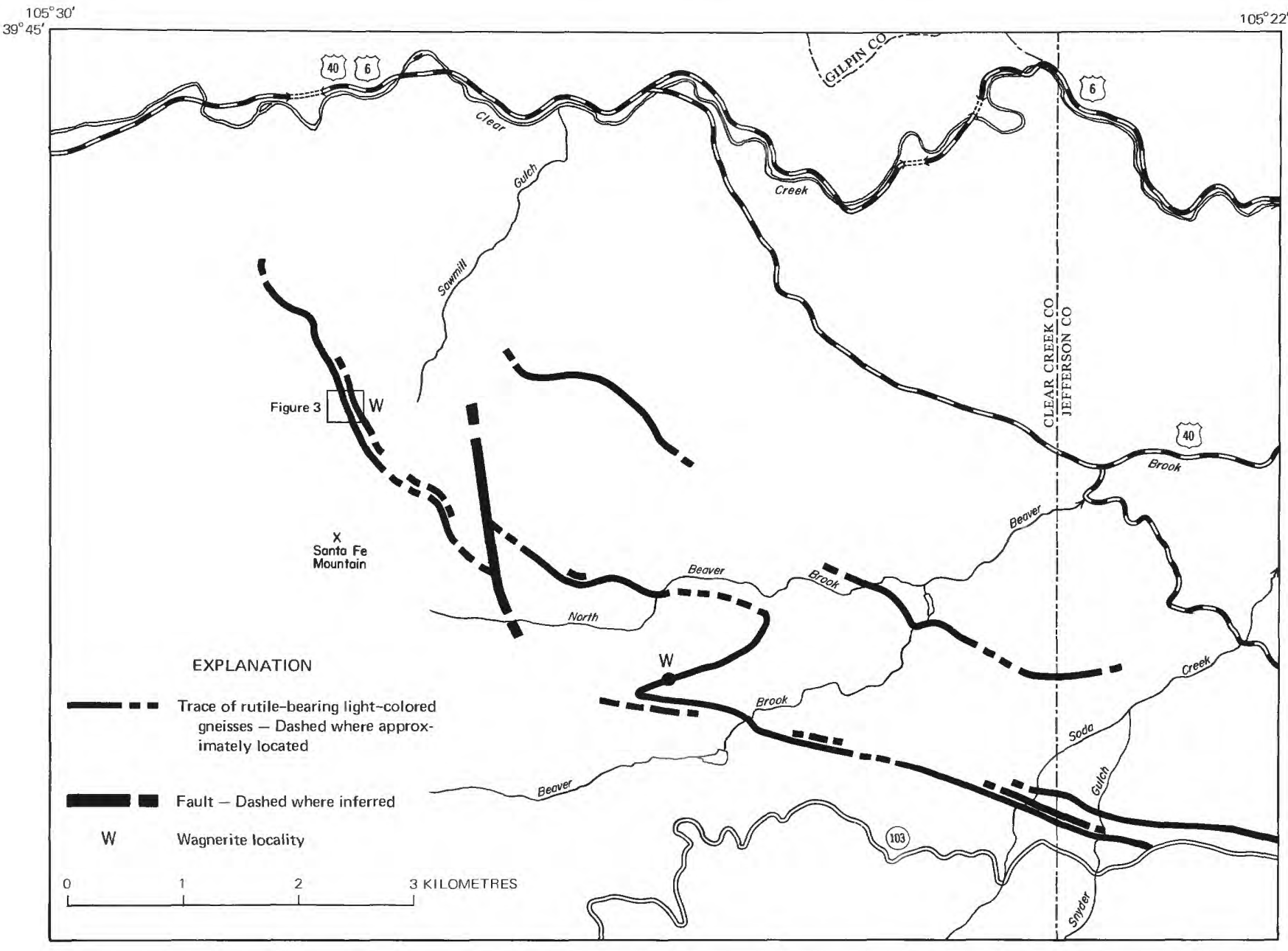

FiguRE 2.-Map showing distribution of rutile-bearing light-colored gneisses in the Santa Fe Mountain-Beaver Brook-Soda Creek area.

The rutile-bearing light-colored gneisses are composed of several lithologic varieties that are interlayered and gradational along strike. The most common varieties are sillimanite-quartz gneiss, biotite-quartz-plagioclase gneiss, and rocks gradational between these two types. Less common regionally, but locally predominant, is a sillimanitic topaz-quartz gneiss (Sheridan and others, 1968), which is present in several localities between Santa Fe Mountain and the eastern margin of the Front Range. At Santa Fe Mountain a local variant of the rutile-bearing light-colored gneisses is a sillimanite-plagioclase gneiss containing wagnerite and corundum.

\section{OCCURRENCE}

At the Santa Fe Mountain wagnerite locality, rutilebearing light-colored biotite-quartz-plagioclase gneiss forms two northwest-trending layers that are separated by hornblende gneiss (fig. 3). Wagnerite occurs in a corundum-bearing sillimanite-plagioclase gneiss that forms a lens within the biotite-quartz-plagioclase gneiss in the eastern layer and that interfingers with biotitequartz-plagioclase gneiss in the western layer. Small bodies of simple quartz-feldspar pegmatite intrude the succession of metamorphic rocks here as they do ubiquitously throughout the Precambrian terrane of the east-central Front Range.

Although rutile-bearing gneisses at this stratigraphic level persist continuously for $1.5 \mathrm{~km}$ to the northwest and for $11.5 \mathrm{~km}$ to the southeast (fig. 2), the principal occurrence of wagnerite is within the area shown in figure 3. Wagnerite has also been identified as a trace constituent of rutile-bearing biotite-quartz-plagioclase gneiss in the area between Beaver Brook and North Beaver Brook (fig. 2).

The wagnerite-bearing sillimanite-plagioclase gneiss is white or light gray, fine to coarse grained, poorly foliated, and texturally complex. Aggregates of prismatic sillimanite, as much as $12 \mathrm{~cm}$ long and $1 \mathrm{~cm}$ thick, and grains of corundum, as long as $2.3 \mathrm{~cm}$, are diversely oriented in a fine- to medium-grained matrix rich in plagioclase and 

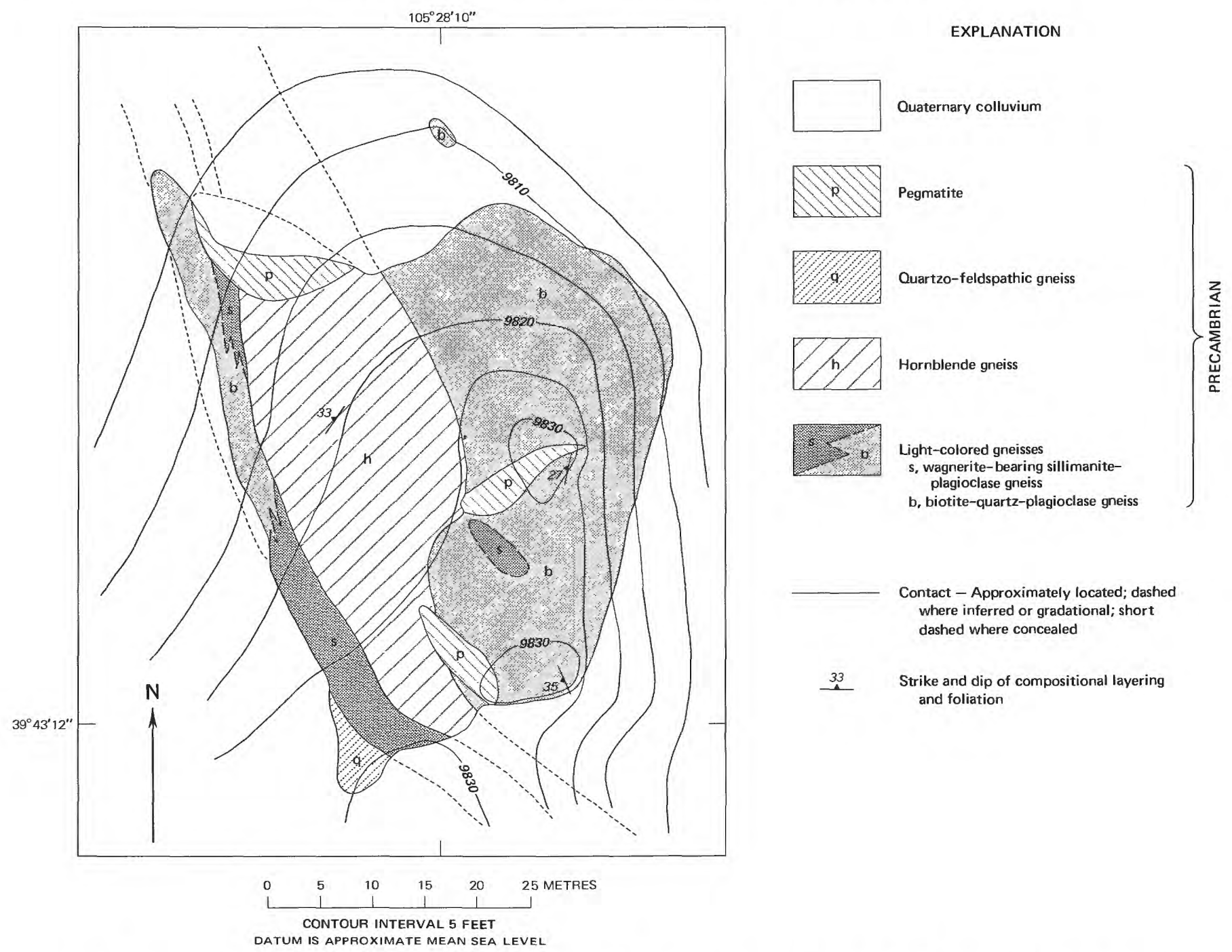

FIGURE 3.-Geologic map of wagnerite locality, Santa Fe Mountain. Geology and topography by D. M. Sheridan and S. P. Marsh.

fibrolitic sillimanite. Wagnerite is recognizable in hand specimens and outcrops as aggregates of small yellow to yellowish-tan grains that commonly are complexly intergrown with other minerals of the rock. Such aggregates are generally small, mostly 2 to $5 \mathrm{~mm}$ across. Smaller individual grains of wagnerite are also common but are recognized readily only in thin section. Other constituents of the gneiss are biotite, rutile, apatite, monazite, zircon, tourmaline, muscovite, and, locally, chlorite. Foliation in the sillimanite-plagioclase gneiss is in general obscure in the outcrops, owning to the diversely oriented large grains of corundum and aggregates of prismatic sillimanite. In some thin sections, however, foliation is well shown and is defined by aggregates of fibrolitic sillimanite, elongate grains of plagioclase, and oriented flakes of biotite.

Modes of the light-colored gneisses of the wagnerite locality were determined by the point-count method $(1,000$ points each) and are reported in table 1. Modes 1-7 represent wagnerite-rich rocks in which plagioclase and sillimanite are the principal constituents. Modes 8 and 9 represent wagnerite-bearing rock with more biotite than sillimanite. Because rock specimens for these thin sections were selected preferentially to study the wagnerite, the modes do not represent normal mineralogic percentages. We estimate that wagnerite and corundum each form about 1 percent of the average rock and that rutile makes up 1-2 percent. In the sillimanite-plagioclase gneiss, quartz is present only in trace amounts as tiny rounded inclusions in other minerals.

The biotite-quartz-plagioclase gneiss, the associated hornblende gneiss, and the quartzo-feldspathic gneiss (fig. 3 ) are fine to medium grained moderately well foliated rocks. Some parts of the hornblende gneiss and the lightcolored biotite-quartz-plagioclase gneiss show welldeveloped compositional layering on a scale of a few centimetres, but other parts contain massive layers $1 \mathrm{~m}$ thick. 
TABLE 1.-Modes (volume percent) of light-colored gneisses, Santa Fe Mountain wagnerite locality, Colorado

\begin{tabular}{|c|c|c|c|c|c|c|c|c|c|c|c|c|}
\hline \multirow{3}{*}{ 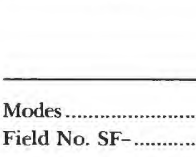 } & \multicolumn{9}{|c|}{ Wagnerite-bearing sillimanite-plagioclase gneiss } & \multicolumn{3}{|c|}{$\begin{array}{c}\text { Biotite-quartz-plagioclase } \\
\text { gneiss }\end{array}$} \\
\hline & 1 & 2 & 3 & 4 & 5 & 6 & 7 & 8 & 9 & 10 & 11 & 12 \\
\hline & $11-4 \times 2$ & $11-6 \mathrm{X}$ & $21 \mathrm{~A}$ & $24 A X$ & $11-8 \times 2$ & S $3 x$ & 23Al & $11-2 X$ & $11-3 x$ & $7 \mathrm{~A}$ & $9 \mathrm{~A}$ & $9 \mathrm{D}$ \\
\hline Quartz............... & Trace & & & ........ & ....... & ....... & ....... & ....... & Trace & 29.3 & 38.8 & 36.0 \\
\hline Plagioclase ...... & 74.4 & 47.3 & 71.6 & 64.7 & 45.7 & 52.4 & 53.0 & 74.6 & 68.8 & 56.3 & 50.5 & 46.7 \\
\hline Microcline ........ & $\ldots . . .$. & $\ldots . .$. & $\ldots \ldots$ & $\ldots \ldots$ & $\ldots \ldots$ & ....... & $\ldots . .$. & ...... & ...... & .2 & ....... & ...... \\
\hline Sillimanite....... & 12.8 & 45.0 & 19.8 & 25.7 & 38.9 & 35.5 & 28.5 & 2.2 & 3.3 & ...... & ….... & 2.0 \\
\hline Biotite.................. & 1.5 & ...... & .1 & ...... & .3 & ....... & .3 & 14.0 & 10.2 & $\dddot{12.5}$ & 4.6 & 10.8 \\
\hline \multicolumn{13}{|l|}{ Muscovite } \\
\hline (and Sericite) & 4.8 & 1.8 & 2.0 & .8 & 3.7 & 1.0 & 4.5 & 3.3 & 10.1 & 1.0 & 4.4 & 3.3 \\
\hline Wagnerite........ & .7 & .9 & 4.6 & 6.8 & 6.9 & 7.6 & 10.9 & 1.4 & .3 & $\ldots .0$ & 1.1 & ....... \\
\hline Apatite.............. & .3 & .3 & $\begin{array}{r}1.0 \\
.3\end{array}$ & $\begin{array}{r}0.0 \\
.6\end{array}$ & $\begin{array}{l}0.3 \\
2.1\end{array}$ & 2.4 & 1.2 & $\begin{array}{r}1.7 \\
.5\end{array}$ & .2 & $\ldots \ldots$ & $\cdots \cdots$ & …... \\
\hline Rutile ................ & 4.8 & 4.7 & .9 & 1.0 & .1 & $\begin{array}{l}.1 \\
.8\end{array}$ & 1.0 & 3.1 & 3.1 & .1 & 5 & 2 \\
\hline 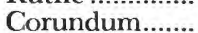 & $\ldots .0$ & 1.2 & .7 & $\ldots$ & 2.2 & .3 & $\ldots . .$. & .5 & 1.5 & $\ldots .$. & $\ldots$. & ...... \\
\hline \multirow{4}{*}{$\begin{array}{l}\text { Monazite and } \\
\text { (or) zircon .... } \\
\text { Tourmaline..... } \\
\text { Chlorite........... }\end{array}$} & & & & & & & & & & & & \\
\hline & .2 & Trace & Trace & Trace & .1 & Trace & .3 & .4 & .2 & Trace & Trace & Trace \\
\hline & ...... & ....... & ....... & ....... & ....... & & ...... & ...... & $\ldots . .$. & ....... & .1 & \\
\hline & .5 & ........ & Trace & .2 & Trace & Trace & .3 & $\ldots . .$. & 2.3 & .6 & 1.1 & 1.0 \\
\hline Total..... & 100.0 & 100.0 & 100.0 & 100.0 & 100.0 & 100.0 & 100.0 & 100.0 & 100.0 & 100.0 & 100.0 & 100.0 \\
\hline
\end{tabular}

Modes 10-12 of biotite-quartz-plagioclase gneiss (table 1) indicate that the principal constituents, in order of increasing abundance, are biotite, quartz, and plagioclase. Rutile (no more than 0.5 percent) is less abundant than in the wagnerite-bearing rock. Wagnerite was not observed in samples of the biotite-quartz-plagioclase gneiss from the Santa Fe Mountain locality.

\section{DESCRIPTIVE MINERALOGY METHODS USED FOR OPTICAL DETERMINATKONS}

Except for optic angles, all optical data for wagnerite and other minerals from Santa Fe Mountain (tables 2, 4) were obtained on single grains that were selected from mineral separates and that were studied petrographically by the spindle-stage procedures described by Wilcox (1959). Most of the determinations of refractive indices were made by use of the focal masking techniques described in detail by Cherkasov (1955a, b; 1957). A few determinations of refractive indices were made by the Becke line method; an interference filter was used that passes a wavelength near the $D$-line of the spectrum. All except one of the optic angles reported in table 2 were determined from thin sections mounted in a universal stage. The exception was determined on the spindle stage using Mallard's method for a centered acute bisectrix figure.

The refractive indices of 3 grains of wagnerite from Bamle, Norway (U.S. Natl. Mus. spec. C4151), reported in table 3 , were determined by spindle state procedures and focal masking techniques. Our measurement of the optic angle of each of these grains was facilitated by $\mathrm{I}$. J. Witkind, who carefully mounted each grain so that its optic plane was normal to the spindle axis. The measurement of the optic angle was then made directly by simple rotation of the spindle from one melatope to the other.

\section{WAGNERITE}

The wagnerite from Colorado is anhedral, mostly fine grained but ranging to medium grained, and pale yellow to yellowish $\tan$. The luster is vitreous to slightly resinous. Cleavage $(100)$ is very poor and other cleavage was not observed. The specific gravity, determined by Fahey's method (Fahey, 1961) on the material ground for chemical analysis, is 3.13. In transmitted light the wagnerite in thin section is colorless; large grains in immersion mounts are faintly yellowish and nonpleochroic. The mineral is biaxial positive. The indices of refraction and $2 V$ (table 2) show a range in values: $\alpha=1.565-1.571, \beta=1.567-1.572$, $\gamma=1.578-1.585$ (all \pm 0.002$) ;(+) 2 V=28^{\circ}-33^{\circ}\left( \pm 1^{\circ}\right)$. Slight

TABLE 2.-Optical data for wagnerite from Santa Fe Mountain, Colorado

\begin{tabular}{|c|c|c|c|c|c|}
\hline \multirow{2}{*}{$\begin{array}{l}\text { Sample } \\
\text { No. SF- }\end{array}$} & \multicolumn{3}{|c|}{ Indices of refraction $( \pm 0.002)^{1}$} & \multirow{2}{*}{$\begin{array}{l}\text { Sample } \\
\text { No. SF- }\end{array}$} & \multirow{2}{*}{$\frac{\text { Optic angle (measured) }}{(+) 2 V}$} \\
\hline & $\alpha$ & $\beta$ & $\gamma$ & & \\
\hline $\begin{array}{l}11-7 \ldots \ldots \ldots . \\
21 \ldots \ldots \ldots \ldots . . \\
24, \mathrm{No} .1 \ldots . \\
23-\mathrm{A} 1 \ldots \ldots \ldots . \\
21 \mathrm{~A} . \ldots \ldots \ldots . . \\
24, \text { No. } 3 \ldots . . \\
24, \text { No. } 2 \ldots .\end{array}$ & $\begin{array}{l}1.565 \\
1.566 \\
.566 \\
1.568 \\
.569 \\
.569 \\
.571\end{array}$ & $\begin{array}{c}1.567-1.568 \\
1.567 \\
1.568 \\
1.570 \\
1.571 \\
1.570 \\
1.572\end{array}$ & $\begin{array}{c}1.578-1.579 \\
1.580 \\
1.581 \\
1.582 \\
1.583 \\
1.583 \\
1.585\end{array}$ & $\begin{array}{l}24 \mathrm{AX} . \\
23 \mathrm{~A} 1 \ldots \\
11-2 \ldots . \\
11-7 \ldots \\
11-4 \ldots \\
21 \mathrm{~B} \ldots . . \\
21 \mathrm{~A} \ldots . . \\
24 \mathrm{~B} \ldots . . \\
23 \mathrm{~B} 2 \mathrm{X}\end{array}$ & 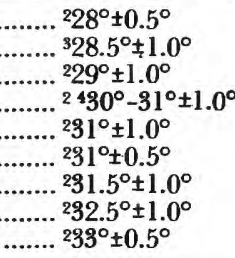 \\
\hline
\end{tabular}

'Determined by spindle stage techniques.

${ }^{2}$ Determined from thin sections on universal stage.

'Determined on spindle stage from centered acute bisectrix figure by Mallard's method.

'Zoned. 
variation of optical properties occurs within many individual grains, a variation limited to $1^{\circ}$ or less in $2 \mathrm{~V}$ and to correspondingly small changes in indices. The birefringence $(\gamma-\alpha)$, calculated from refractive index determinations, ranges from 0.013 to 0.015 . Dispersion is $r>v$, weak. The extinction angle $(\mathrm{Z} \wedge c)$ was measured at approximately $23^{\circ}$ by universal stage techniques in one thin section, but the $(100)$ cleavage is so poorly developed that a representative value for $\mathrm{Z} \wedge c$ cannot be reported. The.optical data for wagnerite from Santa Fe Mountain are compared with optical data for wagnerite from several other localities in table 3.

As viewed in thin section, individual grains of wagnerite range in size from 0.02 to $6.1 \mathrm{~mm}$. Most individual grains are in the size range $0.2-0.6 \mathrm{~mm}$. Aggregates of wagnerite grains, complexly intergrown with plagioclase and other minerals of the rock, are also common, ranging in size from $1 \mathrm{~mm}$ to $12 \mathrm{~mm}$ but most commonly in the size range 2-5 $\mathrm{mm}$. One elongate aggregate observed in hand specimen is $20 \mathrm{~mm}$ long but is so complexly intergrown with other minerals that no more than 50 percent of the aggregate is wagnerite.

TABLE 3.-Comparison of optical data for wagnerite

\begin{tabular}{|c|c|c|c|c|c|}
\hline \multirow{2}{*}{ Locality } & \multirow{2}{*}{$\begin{array}{c}\text { Source of } \\
\text { data }\end{array}$} & \multicolumn{3}{|c|}{ Indices of refraction } & \multirow[b]{2}{*}{$(+) 2 V$} \\
\hline & & $\alpha$ & $\beta$ & $y$ & \\
\hline \multirow{2}{*}{$\begin{array}{l}\text { Santa Fe } \\
\text { Mountain, } \\
\text { Colo......... }\end{array}$} & & & & & \\
\hline & (a) & $\begin{array}{l}1.565-1.571 \\
\pm 0.002\end{array}$ & $\begin{array}{c}1.567-1.572 \\
\pm 0.002\end{array}$ & $\begin{array}{l}1.578-1.585 \\
\pm 0.002\end{array}$ & $\begin{array}{c}28^{\circ}-33^{\circ} \\
\pm 1^{\circ}\end{array}$ \\
\hline Bamle, & & & & & \\
\hline Norway ... & (b) & $\begin{array}{l}1.569-1.571 \\
\pm 0.002\end{array}$ & $\begin{array}{l}1.570-1.572 \\
\pm 0.002\end{array}$ & $\begin{array}{l}1.582-1.584 \\
\pm 0.002\end{array}$ & $\begin{array}{c}37^{\circ}-3812^{\circ} \\
\pm 1^{\circ}\end{array}$ \\
\hline Do.......... & (c) & 1.569 & 1.570 & 1.582 & $136^{\circ} 50^{\prime}$ \\
\hline $\begin{array}{l}\text { Werfen, } \\
\text { Austria .... }\end{array}$ & (d) & 15678 & 5719 & 15824 & $128^{\circ} 24^{\prime}$ \\
\hline Kyakhta, & & & & & \\
\hline U.S.S.R... & (e) & $\begin{array}{r}1.577 \\
\pm 0.001\end{array}$ & $\begin{array}{r}1.582 \\
\pm 0.001\end{array}$ & $\begin{array}{r}1.595 \\
\pm 0.001\end{array}$ & $\begin{array}{l}32^{\circ} \\
\pm 1^{\circ}\end{array}$ \\
\hline 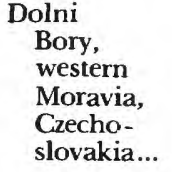 & (f) & 1.568 & 1.571 & 1.582 & Small. \\
\hline
\end{tabular}

Sources of data:

(a) This report (table 2).

(b) This report. The indices reported here are the range in values obtained by spindle-stage techniques on 3 grains of wagnerite, U.S. Natl. Mus. spec. C4151 from Bamle, Norway. Measurement of $2 V_{2}$ was done by orienting the optic plane of each grain normal to the spindle axis; in this manner, measurement of the optic angle was made directly by rotation of the spindle from one melatope to the other.

(c) Indices of refraction from Michel-Lévy and Lacroix (1888, p. 290). The $2 V$ was calculated from $2 E=59^{\circ} 30^{\prime}$, reported by Doelter $(1918$, p. 319).

(d) Indices of refraction from Hegemann and Steinmetz (1927, p. 55). The $2 V$ was calculated from $2 E=45^{\circ} 2212^{\prime}$, reported by Hegemann and Steinmetz (1927, p. 55).

(e) Finko (1962, p. 1425).

(f) Stanと̌k (1965, p. 67).
The wagnerite appears to be entirely anhedral; no crystal faces were observed despite the study of numerous thin sections. Most commonly the individual grains are elliptical to very irregular or ameboid (fig. 4) in shape. The larger grains tend to be blocky to rounded and have very irregular boundaries (fig. 5). Some of these grains contain myriads of small inclusions of rutile; others poikiloblastically enclose small grains of plagioclase, sillimanite, monazite, and other minerals.

Some groups of closely spaced wagnerite grains seem to be composed of distinct individuals that are separated by plagioclase and other minerals of the rock. When viewed through crossed polars, however, most of the wagnerite grains in such groups have identical interference color and come to extinction at the same position. Very likely such wagnerite grains are connected in the third dimension and represent a type of branching skeletal growth, which, in the plane of the thin section, shows up mainly as a complex intergrowth approaching that of a poikiloblastic texture (fig. 6).

In addition to poikiloblastic inclusions of grains of other minerals of a size large enough to be readily identi-

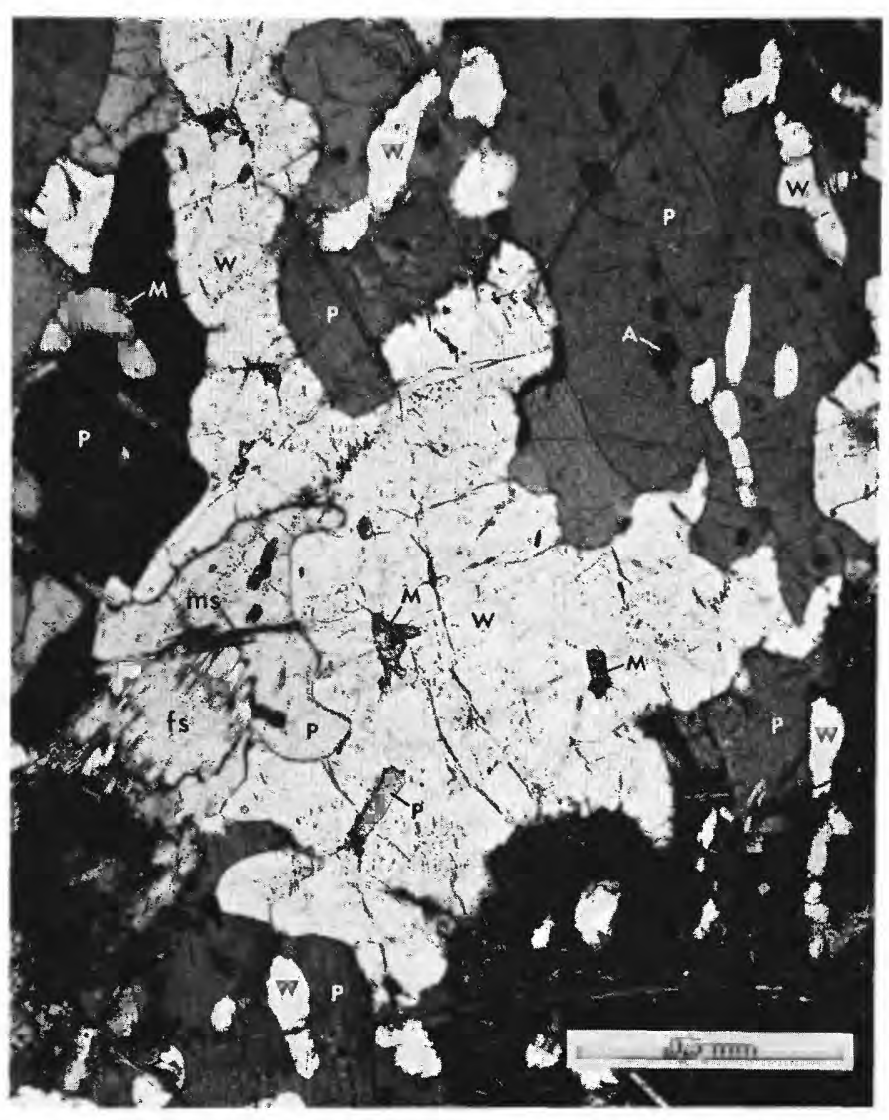

FIGURE 4.-Large grain of wagnerite (W) occupying central part of photomicrograph is ameboid in shape; smaller grains of wagnerite are elliptical to irregular. Other minerals are plagioclase $(P)$, monazite (M), apatite (A), fibrolitic sillimanite (fs), and muscovite (ms). Crossed polars. 


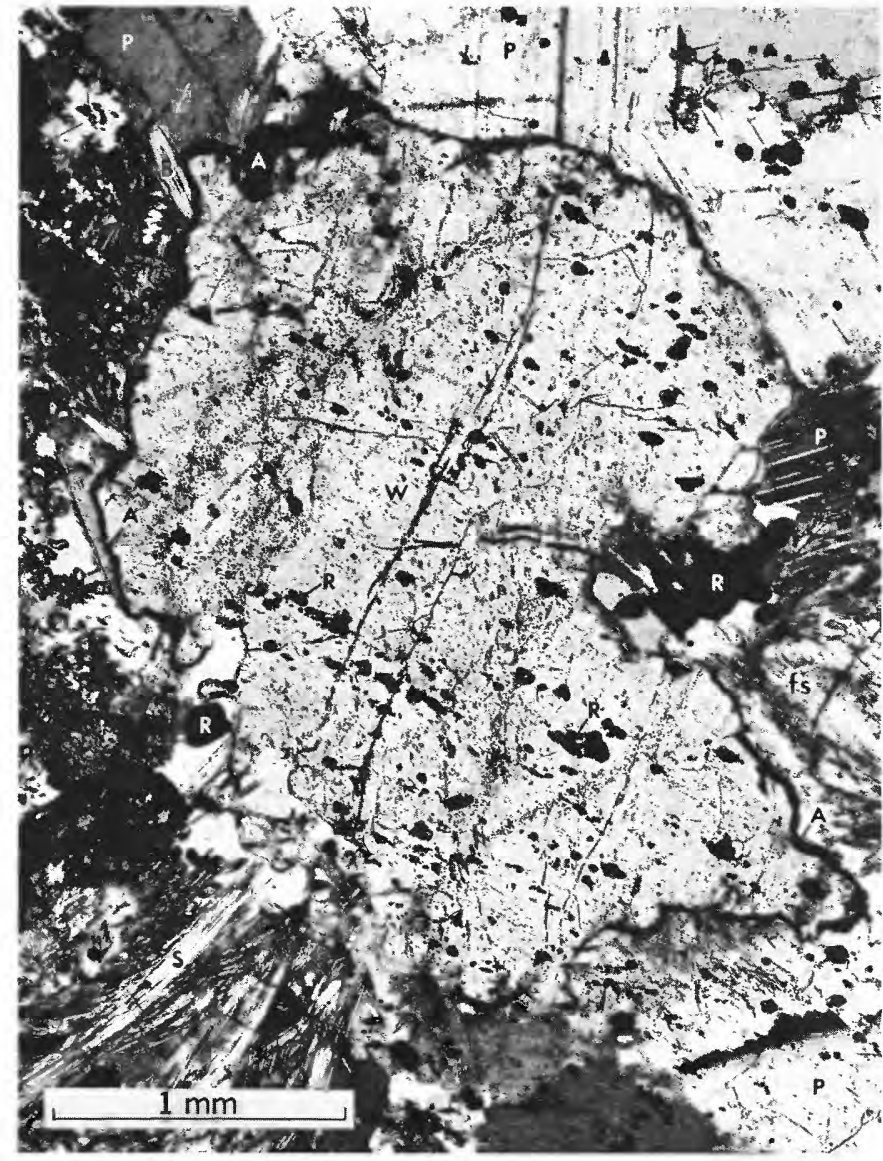

Figure 5.-Large blocky grain of wagnerite (W) poikiloblastically encloses rows of grains of rutile (R). Apatite (A) forms a thin rim along the boundary of the wagnerite grain. Other minerals are plagioclase $(P)$, biotite $(B)$, fibrolitic sillimanite (fs), and prismatic sillimanite (S). Crossed polars.

fiable in thin section, many of the medium to large grains of wagnerite show cloudy areas crowded with abundant very tiny inclusions. At low to moderate magnification in plane-polarized light, these cloudy areas are bluish. Commonly, the cloudy areas are located at or near the center of the wagnerite grains, and the surrounding borders of wagnerite are relatively clear of inclusions; in other wagnerite grains, the cloudy areas are located asymmetrically near the edge of the grains (fig. 9). A photomicrograph (fig. 7), taken at high magnification with upper and lower polars removed, shows part of a wagnerite grain clouded with tiny inclusions. Toward the center of the clouded area, the inclusions are principally equidimensional with rounded form, and they commonly range in size from 0.0005 to $0.01 \mathrm{~mm}$. Toward the edge of the clouded area, elongate prismatic inclusions, as long a $0.1 \mathrm{~mm}$, are more abundant and are alined in a rectilinear pattern. Identification of these tiny inclusions proved impossible by ordinary petrographic methods in thin section, but an attempt was made to learn their mineralogic nature by other methods. During the

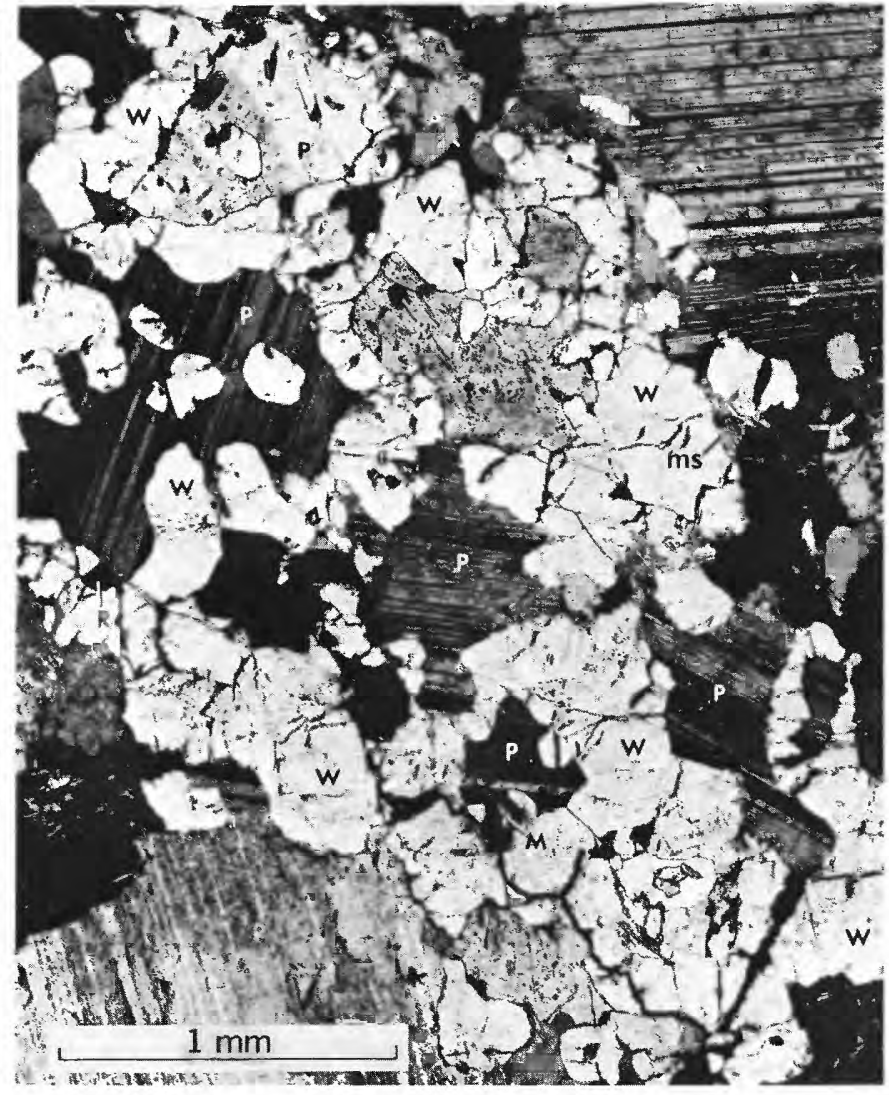

FIGURE 6.-Complex intergrowth of closely spaced grains of wagnerite (W) and plagioclase (P). However, as most of the wagnerite grains shown here have the same interference color and come to extinction at the same position, they are probably interconnected in the third dimension and comprise a complex branching skeletal or poikiloblastic growth. Other minerals are rutile (R), monazite (M), apatite (A), and muscovite (ms). Crossed polars.

chemical analysis of wagnerite, the analytical procedure involved digestion of part of the sample in nitric acid. The insoluble residue from this digestion was studied carefully by Mrose through X-ray techniques. This residue, which represents at least part of the inclusions, was found to be sillimanite, rutile, and quartz, plus minor mica and xenotime. If apatite or any other mineral soluble in nitric acid were present as part of the suite of tiny inclusions in the wagnerite, it probably was dissolved during the analytical procedure.

Although many of the wagnerite grains are in direct contact with the other minerals of the rock, many others show a partial to complete enveloping film of apatite (fig. 8). Each rim is formed of a single optically continuous apatite crystal. The thickness of the rim ranges from less than $0.01 \mathrm{~mm}$ to $0.2 \mathrm{~mm}$ but most commonly is about 0.02 $\mathrm{mm}$. Although the rims of apatite are perhaps most commonly present between wagnerite and plagioclase or fibrolitic sillimanite, they have also been observed between wagnerite and other minerals of the rock, such as biotite, monazite, rutile, muscovite, and chlorite. Where 


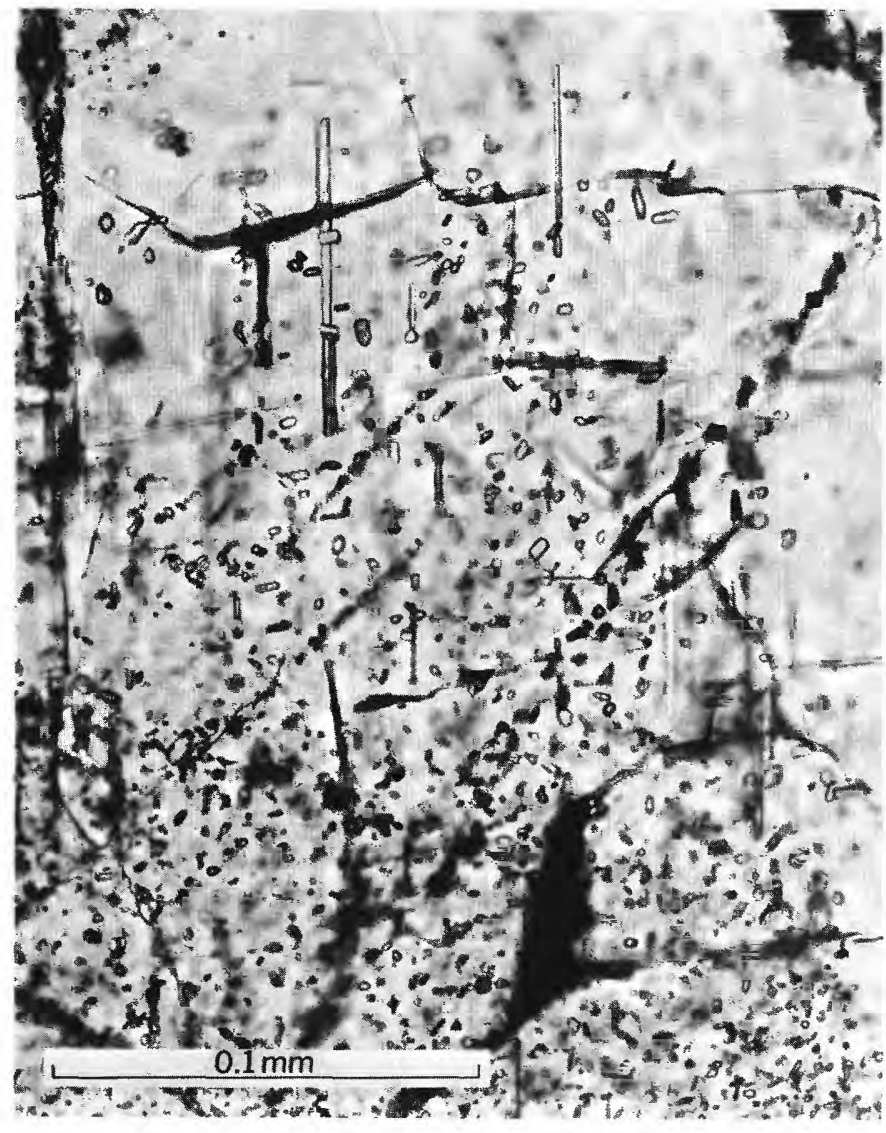

Figure 7.-Part of a large wagnerite grain that is crowded with tiny inclusions. Bottom of photomicrograph is toward the interior of wagnerite grain and shows abundant equidimensional to rounded inclusions. Top of photomicrograph is near edge of wagnerite grain and is relatively free of inclusions. Between the clear edge and the densely clouded interior, elongate prismatic inclusions are alined in rectilinear fashion. Inclusions are chiefly sillimanite, rutile, and quartz. Photomicrograph taken with upper and lower polars removed.

two or more wagnerite grains are closely spaced in the rock, the apatite rims commonly coalesce over part of their extent, forming the thicker observed portions of such rims. Some of the larger wagnerite grains not only have an external rim of apatite but also have internal rims of apatite bordering poikiloblastic inclusions of small grains of plagioclase and other minerals of the rock. Although commonly composed of clear apatite, in one instance the apatite rim has formed around a wagnerite grain containing an asymmetrically located area clouded with tiny inclusions (fig. 9); where the cloudy area extends to the edge of the wagnerite grain, the apatite rim is also crowded with abundant tiny inclusions.

In some thin sections the wagnerite has been partly altered to an unidentified fine-grained material which appears brownish in plane-polarized light and which has no conspicuous identifiable characteristics when viewed with crossed polars or when examined by conoscopic study.

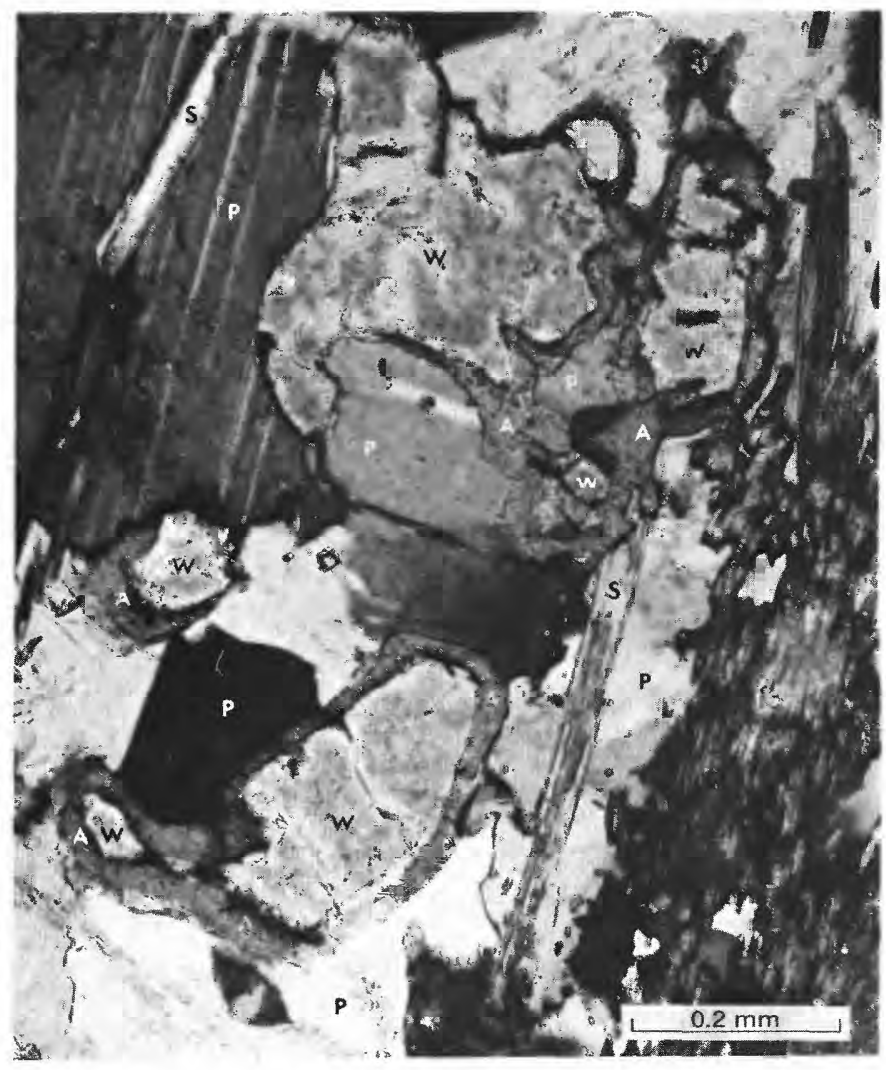

FIGURE 8.-Apatite (A) forms rims on wagnerite (W). Wagnerite grain at top center has only a partial rim of apatite, but all other wagnerite grains shown here are completely rimmed by apatite. Rims on several grains at top center and upper right coalesce and surround a small grain of plagioclase $(P)$. Other minerals are fibrolitic sillimanite (fs) and prismatic sillimanite (S). Crossed polars.

\section{OTHER MINERALS}

The optical characteristics of the associated minerals from the Santa Fe Mountain wagnerite-bearing rocks were also studied. These properties together with those of some of the minerals of the associated rocks are reported in table 4.

Plagioclase.-The plagioclase of the wagnerite-bearing sillimanite-plagioclase gneiss is albite $\left(\mathrm{An}_{6}-\mathrm{An}_{8}\right)$, as determined in two samples (SF-21 and SF-24A, table 4). Commonly showing well-developed albite twinning (figs. $6,12)$, the plagioclase grains are elongate parallel to the foliation; they range in length from 0.04 to $7 \mathrm{~mm}$ but most commonly are about $1.2 \mathrm{~mm}$. The plagioclase in biotitequartz-plagioclase gneiss (SF-7A, table 4) is also albite $\left(\mathrm{An}_{6}\right)$ and occurs as grains averaging about $0.6 \mathrm{~mm}$ in length. The plagioclase of these light-colored gneisses is more sodic than the plagioclase of the darker colored metamorphic rocks in this area. Plagioclase in the hornblende gneiss (SF-20B, table 4$)$ is andesine $\left(\mathrm{An}_{31}\right)$; and plagioclase in the quartzo-feldspathic gneiss is oligoclase $\left(\mathrm{An}_{27}\right)$. 


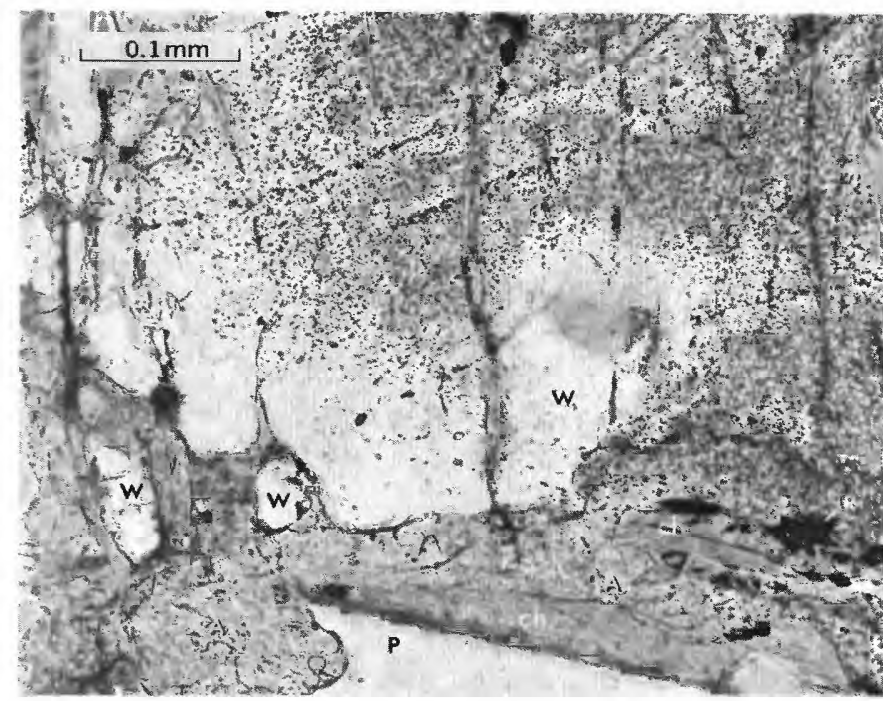

FIGURE 9.-Large grain of wagnerite (W) occupies upper two-thirds of photomicrograph and is rimmed by apatite (A), which completely encloses two smaller grains of wagnerite at left. Where the edge of large wagnerite grain is clear and relatively free from tiny inclusions, as at left center, the adjoining apatite rim is also clear. Where edge of large wagnerite grain is clouded with tiny inclusions, as at right, the adjoining apatite rim is also clouded with inclusions. Other minerals are plagioclase $(P)$, rutile $(R)$, and chlorite (ch). Polars partly crossed.

Biotite.-Most of the biotite in the sillimaniteplagioclase gneiss and the biotite-quartz-plagioclase gneiss is very pale brown, as viewed under the hand lens and in thin section. It resembles the biotite found in the cordierite-bearing biotite gneisses of the east-central Front Range (Gable and Sims, 1969, p. 39) rather than the darkbrown to black biotite of the more common gneisses. Optical data for pale-brown biotite from two samples of sillimanite-plagioclase gneiss (SF-21; SF-11-3) and from one sample of biotite-quartz-plagioclase gneiss (SF-7A) are reported in table 4 . All three samples of biotite are biaxial negative $\left(2 \mathrm{~V}\right.$ estimated no more than $\left.10^{\circ}\right)$. Comparison of the $\beta$ index (ranging from 1.584 to 1.595) with Winchells' graph (Winchell and Winchell, 1951, p. 374) suggests that this is a low-iron, high-magnesium variety; thus the biotite is probably close to the phlogopite-eastonite part of the compositional field. Biotite flakes range in size from 0.02 to $2.6 \mathrm{~mm}$ but average about $0.5 \mathrm{~mm}$ in both of the light-colored gneisses.

Sillimanite.-Sillimanite in the sillimanite-plagioclase gneiss occurs in two varieties. Fibrolitic sillimanite occurs in elongate to elliptical aggregates of tiny needles oriented parallel to the foliation (figs. 11, 12) and other mineral lineations; most aggregates are $0.5-10 \mathrm{~mm}$ long, although locally some are as long as $19 \mathrm{~mm}$. Coarse prismatic sillimanite crystals are diversely oriented in the rock, commonly cutting other minerals (figs. 13, 14). Single prismatic sillimanite crystals generally are $0.1-0.2 \mathrm{~mm}$ thick and 1.5-2 $\mathrm{mm}$ long; aggregates of these crystals are locally as much as $12 \mathrm{~cm}$ long and $1 \mathrm{~cm}$ in diameter. Refractive indices of prismatic sillimanite from two samples (SF-21 and SF-24A, table 4) are at the lower end of the range of values reported by Deer, Howie, and Zussman (1962, p. 121).

Monazite.-Monazite occurs as small, clear, paleyellowish grains. These grains range in size from 0.01 to $0.2 \mathrm{~mm}$ and are commonly associated with rutile and wagnerite. Refractive indices $\alpha$ and $\beta$, determined for sample SF-11-3 (table 4), are in the lower range of values commonly reported.

Apatite.-Two forms of apatite occur in the sillimaniteplagioclase gneiss: (1) individual grains that are rounded to blocky and locally prismatic, clear and colorless to dusky, and about the same average size and distribution as those of wagnerite; (2) partial to complete rims on wagnerite (noted in the description of wagnerite and shown in figs. 5, 8, 9). The apatite that occurs as individual grains ranges in size from 0.02 to $1 \mathrm{~mm}$; aggregates are as much as $6.4 \mathrm{~mm}$ across. Locally, prismatic grains of apatite occur as inclusions in wagnerite (fig. 10). The refractive indices determined for individual grains of apatite from two samples (SF-11 and SF-21, table 4) suggest that it is fluorapatite.

Corundum.-Corundum, ranging in color from pink to grayish, occurs in the sillimanite-plagioclase gneiss in grains ranging in size from $0.04 \mathrm{~mm}$ to $2.3 \mathrm{~cm}$. Many of the larger grains are subhedral to euhedral and show well-

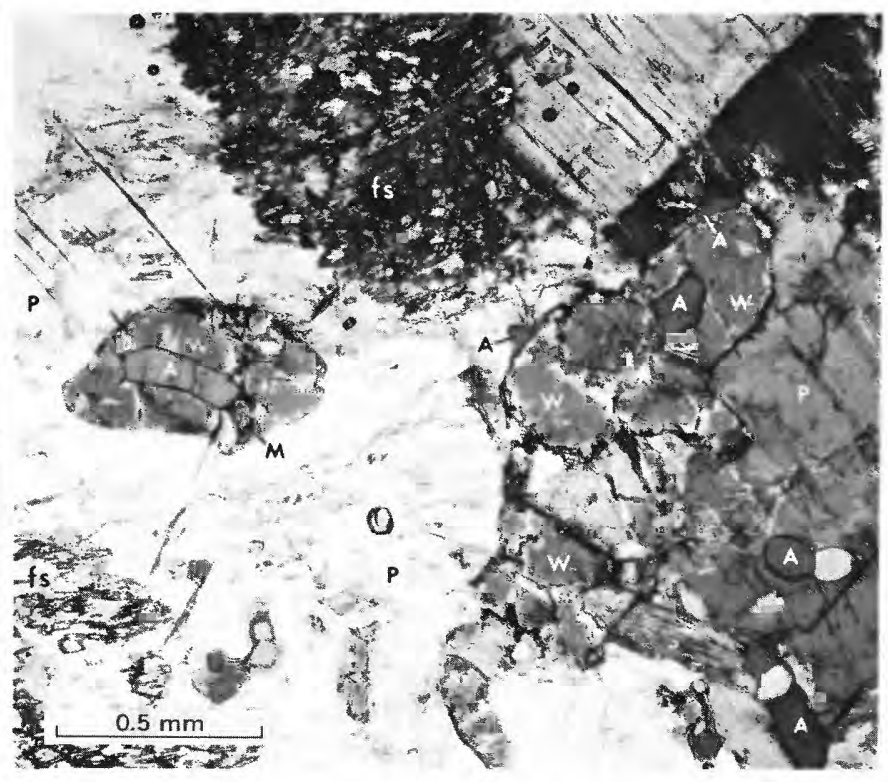

FIgURE 10.-Apatite (A) occurs as prismatic to blocky grains included in wagnerite $(W)$. Other apatite grains are included in plagioclase (P). The wagnerite grain at upper right also has a thin partial rim of apatite. Other minerals are monazite (M), fibrolitic sillimanite (fs), and prismatic sillimanite (S). Crossed polars. 
TABLE 4.-Optical data for other minerals from wagnerite locality, Santa Fe Mountain, Colorado

Biaxial minerals

\begin{tabular}{|c|c|c|c|c|c|c|c|}
\hline \multirow{2}{*}{ Mineral } & \multirow{2}{*}{ Rock type } & \multirow{2}{*}{$\begin{array}{l}\text { Sample } \\
\text { No. } \\
\text { SF- }\end{array}$} & \multicolumn{3}{|c|}{ Indices of refraction ${ }^{2}$} & \multirow{2}{*}{$\begin{array}{l}\text { Optic } \\
\text { sign }\end{array}$} & \multirow{2}{*}{ Remarks } \\
\hline & & & $\bar{\alpha}$ & $\beta$ & $\gamma$ & & \\
\hline Plagioclase .............. & $\begin{array}{l}\text { Sillimanite-plagioclase gneiss con- } \\
\text { taining wagnerite, rutile, and } \\
\text { corundum. }\end{array}$ & 21 & 1.532 & 1.536 & 1.541 & $(+)$ & Composition: ${ }^{2}$ albite $\left(\mathrm{An}_{6}\right)$ \\
\hline Do........................ & 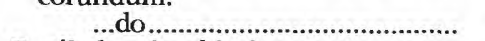 & $24 \mathrm{~A}$ & 1.533 & 1.537 & 1.542 & $(+)$ & Composition: ${ }^{2}$ albite $\left(\mathrm{An}_{8}\right)$. \\
\hline Do........................... & $\begin{array}{l}\text { Rutile-bearing biotite-quartz- } \\
\text { plagioclase gneiss. }\end{array}$ & $7 \mathrm{~A}$ & 1.532 & 1.536 & 1.541 & $(+)$ & Composition: ${ }^{2}$ albite $\left(\mathrm{An}_{6}\right)$. \\
\hline Do........................ & 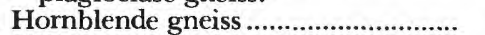 & $20 \mathrm{~B}$ & 1.544 & 1.548 & 1.552 & $(-)$ & Composition: ${ }^{2}$ andesine $\left(\mathrm{An}_{31}\right)$ \\
\hline Biotite...................... & $\begin{array}{l}\text { Sillimanite-plagioclase gneiss con- } \\
\text { taining wagnerite, rutile, and } \\
\text { corundum. }\end{array}$ & 21 & 1.557 & 1.595 & 1.595 & $(-)$ & $\begin{array}{l}\text { Pleochroism: } \\
\quad \begin{array}{l}\alpha=\text { colorless to very pale yellowish tan; } \\
\beta=\gamma=\text { pale brown. }\end{array}\end{array}$ \\
\hline Do......................... & 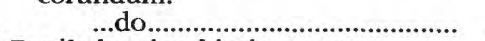 & $11-3$ & 1.548 & 1.584 & 1.584 & $(-)$ & Do. \\
\hline Do........................... & $\begin{array}{l}\text { Rutile-bearing biotite-quartz- } \\
\text { plagioclase gneiss. }\end{array}$ & $7 \mathrm{~A}$ & 1.549 & 1.585 & 1.585 & $(-)$ & Do. \\
\hline Sillimanite.................. & $\begin{array}{l}\text { Sillimanite-plagioclase gneiss } \\
\text { containing wagnerite, rutile, and } \\
\text { corundum. }\end{array}$ & 21 & 1.656 & 1.658 & 1.676 & $(+)$ & Prismatic variety. \\
\hline Do........................ & 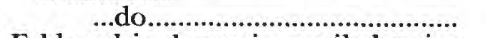 & $24 \mathrm{~A}$ & 1.654 & 1.657 & 1.674 & $(+)$ & Do. \\
\hline Andalusite ............... & $\begin{array}{l}\text { Feldspathic layer in rutile-bearing } \\
\text { biotite-quartz-plagioclase gneiss. }\end{array}$ & $4 F$ & 1.628 & 1.634 & 1.639 & $(-)$ & Pleochroism: $\alpha=$ pink; $\beta=\gamma=$ colorless. \\
\hline Monazite................. & $\begin{array}{l}\text { Sillimanite-plagioclase gneiss } \\
\text { containing wagnerite, rutile, and } \\
\text { corundum. }\end{array}$ & ${ }_{ \pm}^{11-3}$ & $\begin{array}{r}1.787 \\
\pm 0.003 \pm\end{array}$ & $\begin{array}{r}1.788 \\
\pm 0.003\end{array}$ & $\left({ }^{3}\right)$ & $(+)$ & Absorption: $\beta>\alpha=\gamma$ \\
\hline
\end{tabular}

Uniaxial minerals

\begin{tabular}{|c|c|c|c|c|c|c|}
\hline \multirow{2}{*}{ Mineral } & \multirow{2}{*}{ Rock type } & \multirow{2}{*}{$\begin{array}{l}\text { Sample } \\
\text { No. } \\
\text { SF- }\end{array}$} & \multicolumn{2}{|c|}{ Indices of refraction ${ }^{1}$} & \multirow{2}{*}{$\begin{array}{c}\text { Optic } \\
\text { sign }\end{array}$} & \multirow{2}{*}{ Remarks } \\
\hline & & & $\boldsymbol{E}$ & $\omega$ & & \\
\hline Apatite.................... & $\begin{array}{l}\text { Sillimanite-plagioclase gneiss con- } \\
\text { taining wagnerite, rutile, and } \\
\text { corundum. }\end{array}$ & 11 & 1.629 & 1.632 & $(-)$ & \\
\hline Do......................... & 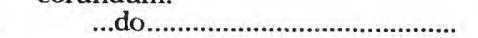 & 21 & 1.631 & 1.635 & $(-)$ & \\
\hline Corundum............... & 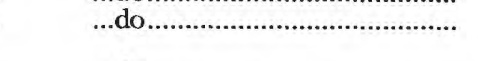 & 15 & $\begin{array}{r}1.759 \\
\pm 0.003\end{array}$ & $\begin{array}{r}1.767 \\
\pm 0.003\end{array}$ & $(-)$ & Pink in hand specimen. \\
\hline Tourmaline............ & 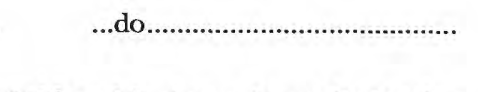 & $11-3$ & 1.615 & 1.638 & $(-)$ & 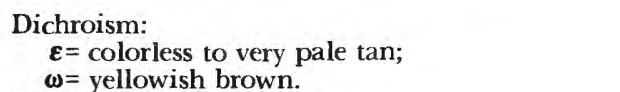 \\
\hline Do...................... & $\begin{array}{l}\text { Feldspathic layer in rutile-bearing } \\
\text { biotite-quartz-plagioclase gneiss. }\end{array}$ & $4 F-1$ & 1.613 & 1.635 & $(-)$ & $\begin{array}{l}\text { Dichroism: } \\
\qquad \begin{array}{l}\boldsymbol{\epsilon}=\text { colorless to very pale blue; } \\
\omega=\text { greenish blue. }\end{array}\end{array}$ \\
\hline 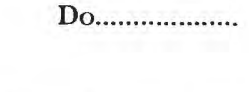 & 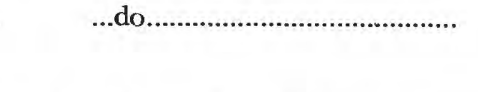 & $4 F-2$ & 1.612 & 1.635 & $(-)$ & $\begin{array}{l}\text { Dichroism: } \\
\varepsilon=\text { very pale blue; } \\
\omega=\text { variegated greenish blue to brownish yellow. }\end{array}$ \\
\hline
\end{tabular}

Precision of refractive index determinations is $\mathbf{\pm 0 . 0 0 2 ~ e x c e p t ~ w h e r e ~ i n d i c a t e d . ~ D e t e r m i n e d ~ b y ~ s p i n d l e ~ s t a g e ~ p r o c e d u r e s . ~}$

2Plagioclase composition determined from curves for low-temperature plagioclase by Smith (1960, pl. 12).

${ }^{3}$ Not determined.

developed pseudohexagonal parting; thin sections of such grains commonly show twinning. Many of the smaller grains of corundum are anhedral to angular kernels, many of which resemble graphic shapes. Such small kernels of corundum, $0.06-1 \mathrm{~mm}$ across, occur as closely spaced individuals that comprise aggregates $3 \mathrm{~mm}$ across in fibrolitic sillimanite clots. Individual grains of corundum within an aggregate commonly have the same interference color and come to extinction at the same position upon rotation of the microscope stage, suggesting that they are connected elements of a single skeletal crystal. Refractive indices for corundum from one sample (SF-15) are reported in table 4.
Andalusite.-Andalusite has been recognized only in a single thin feldspathic layer within the biotite-quartzplagioclase gneiss. It occurs as blocky pinkish-white grains ranging in size from 0.2 to $1 \mathrm{~mm}$, and it is associated with plagioclase, quartz, muscovite, and chlorite. Optical data for andalusite from one sample $(\mathrm{SF}-4 \mathrm{~F})$ are reported in table 4.

Tourmaline.-Tourmaline occurs sparsely in both the sillimanite-plagioclase gneiss and the biotite-quartzplagioclase gneiss. It is fairly common as small yellowishbrown to pale-greenish-blue grains in heavy mineral separates prepared from rock samples; although a few grains were observed in thin sections, none was seen in 
contact with wagnerite. In a sillimanitic biotite-quartzplagioclase gneiss that occurs along the trace of the lightcolored gneiss unit about $100 \mathrm{~m}$ northwest of the wagnerite locality, sparse small aggregates of tourmaline, as much as $2 \mathrm{~cm}$ across, are poikiloblastically intergrown with other minerals of the rock; individual brownish crystals are 2-6 $\mathrm{mm}$ long and $0.5 \mathrm{~mm}$ in diameter. Optical data for tourmaline from rocks of the mapped area (fig. 3) are reported in table 4 . The refractive indices suggest that the tourmaline is dravite.

Other minerals from the wagnerite locality.-Quartz occurs only in trace amounts in the silimanite-plagioclase gneiss, where it is present as small rounded inclusions in other minerals of the rock. In the biotite-quartzplagioclase gneiss, however, quartz is a major constituent occurring as grains ranging from 0.04 to $3.8 \mathrm{~mm}$ in size and averaging about $0.5 \mathrm{~mm}$. Rutile is a characteristic minor constituent of both the light-colored gneisses of the Santa Fe Mountain locality. Commonly splendent red in color, it ranges from yellow to nearly black. Heavy mineral separates indicate that the average rutile content of the sillimanite-plagioclase gneiss is between 1 and 2 percent. The average rutile content of the biotite-quartzplagioclase gneiss is no more than 0.5 percent. Rutile grains range in size from 0.01 to $0.6 \mathrm{~mm}$, but most are in the range of $0.06-0.1 \mathrm{~mm}$. Although most of the rutile grains are anhedral, some are subhedral to euhedral. Zircon, although identified optically in grains picked from heavy mineral separates, does not appear to be as abundant in the sillimanite-plagioclase gneiss as monazite. Xenotime was identified only in the insoluble residue from the chemical analysis of wagnerite. White mica occurs in both the sillimanite-plagioclase gneiss and the biotite-quartz-plagioclase gneiss. All samples of white mica studied by X-ray proved to be muscovite. Many grains of the muscovite are about the same size as biotite (about $0.5 \mathrm{~mm}$ ). Sericite (finely crystalline muscovite) is found in plagioclase and along the boundaries of some of the sillimanite aggregates. Chlorite is fairly common as a minor constituent of both of the light-colored gneisses where it apparently formed as an alteration or pseudomorph of biotite. The chlorite seems to have a birefringence of about 0.010 and is colorless in thin section. Universal-stage study of the chlorite in one thin section (SF-11-3X) of wagnerite-bearing rock indicates that $(+) 2 \mathrm{~V}$ of the mineral is about $13^{\circ}$.

\section{MINERAL ASSEMBLAGES AND TEXTURAL RELATIONS}

During petrographic studies of wagnerite-bearing gneiss, special attention was focused on mineral assemblages and on textures, structures, and intergranular relations. Although one or more of the minerals listed in the following assemblage may be missing from a particular specimen, textural relations indicate that a single stable-state assemblage characterizes this rock: wagnerite + plagioclase (albite) + fibrolitic sillimanite + magnesian biotite. To this assemblage may be added small amounts of rutile, monazite, zircon, and apatite, minerals inferred to represent phases belonging to an early stage of crystallization during the high-grade regional metamorphism. Rock textures indicate that corundum, prismatic sillimanite, and some of the apatite (the form that occurs as rims on wagnerite) crystallized later, but very likely during the same regional metamorphism.

Fibrolitic sillimanite, plagioclase, biotite, and wagnerite define the foliation of the sillimaniteplagioclase gneiss. Commonly elongate aggregates of fibrolitic sillimanite alined in foliation surfaces also form a linear structure. Elongate grains of plagioclase and wagnerite, flattened in the foliation plane, are intergrown to varying degrees. Small grains and grain clusters of wagnerite concentrated at boundaries between other minerals (fig. 11) are strongly oriented in the plane of foliation. Similarly, wagnerite grains enclosed within

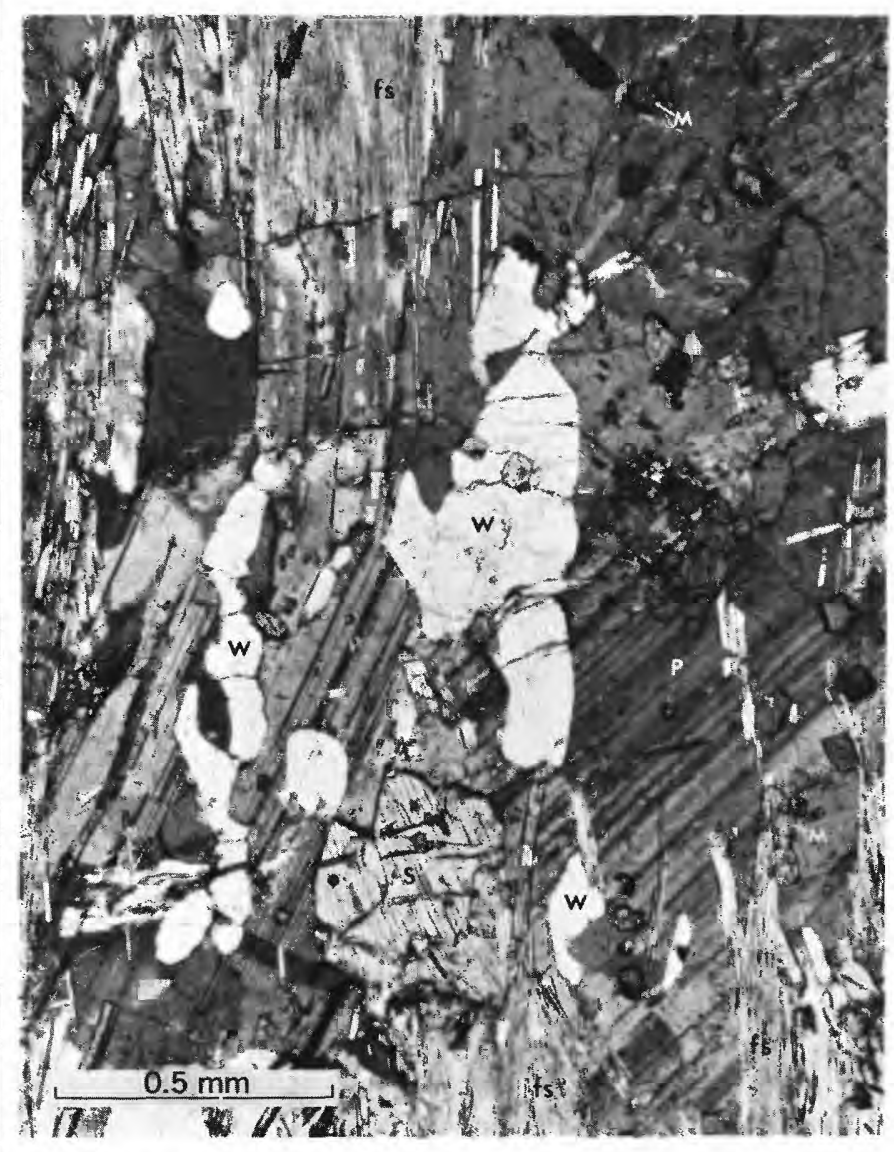

FIGURE 11.-Foliation in sillimanite-plagioclase gneiss is defined by fibrolitic sillimanite ( $f s)$. Grains of wagnerite $(W)$ that are concentrated along grain boundaries of other minerals are also strongly oriented in the plane of the foliation. Other minerals are plagioclase (P), prismatic sillimanite (S), and monazite (M). Crossed polars. 


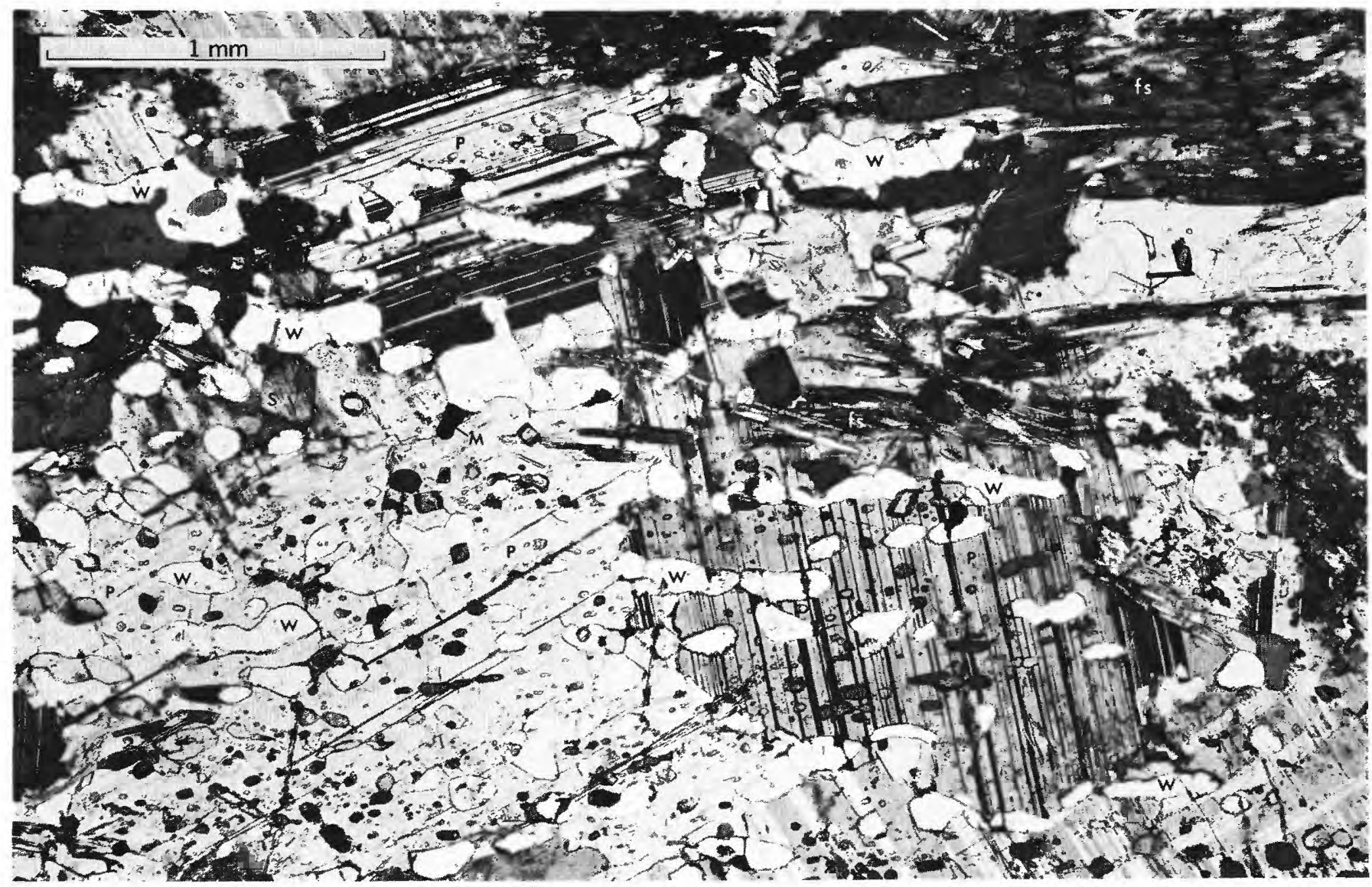

FIGURE 12.-Foliation in sillimanite-plagioclase gneiss is defined by fibrolitic sillimanite (fs). Grains of wagnerite (W) that are enclosed within grains of plagioclase $(P)$ are also strongly oriented in the plane of the foliation. A single optical orientation is shared by numerous grains of wagnerite. Other minerals are monazite (M) and prismatic sillimanite (S). Crossed polars.

single grains of plagioclase commonly are also strongly oriented (fig. 12). In part, such groups of wagnerite grains are complexly intergrown skeletal growths; a single optical orientation is commonly shared by dozens of separate but closely spaced grains. (See figs. $6,12$.$) Such$ common orientation may be confined within a single plagioclase grain or may cross host-crystal boundaries, or a single plagioclase grain may enclose several differently oriented skeletal wagnerite growths. Some of the larger wagnerite grains enclose rows of rutile grains (fig. 5) or may surround other minerals that define the foliate fabric.

In contrast, prismatic sillimanite and corundum in coarse grains disrupt the foliate fabric of the wagneritebearing gneiss. Prismatic sillimanite typically cuts plagioclase, wagnerite, and fibrolitic sillimanite (figs. 13, 14). It cuts across the foliation and fails to parallel the lineation of the fibrolitic sillimanite. Corundum grains similarly interrupt the foliation. Small anhedral corundum grains, groups of small grains in optical continuity, skeletal crystals enclosing other minerals, and large subhedral to euhedral crystals of corundum seem to represent varying stages of crystallization. Characteristically, these

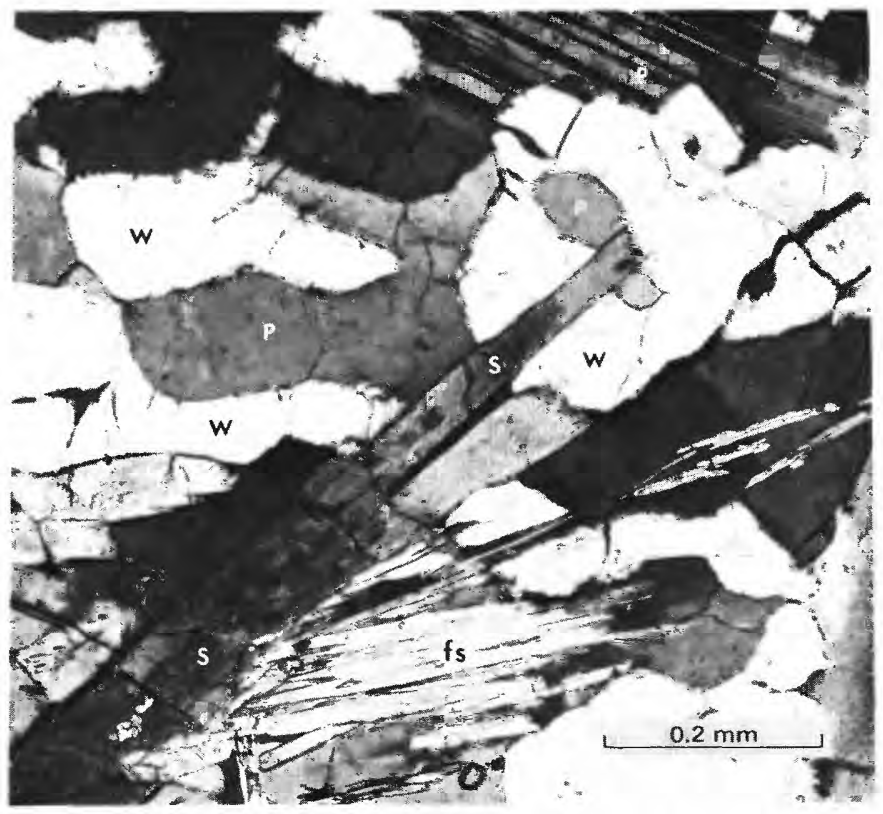

FIGURE 13.-Prismatic sillimanite (S) cuts wagnerite (W) and plagioclase $(\mathrm{P})$. Other grains are fibrolitic sillimanite (fs). Crossed polars. 


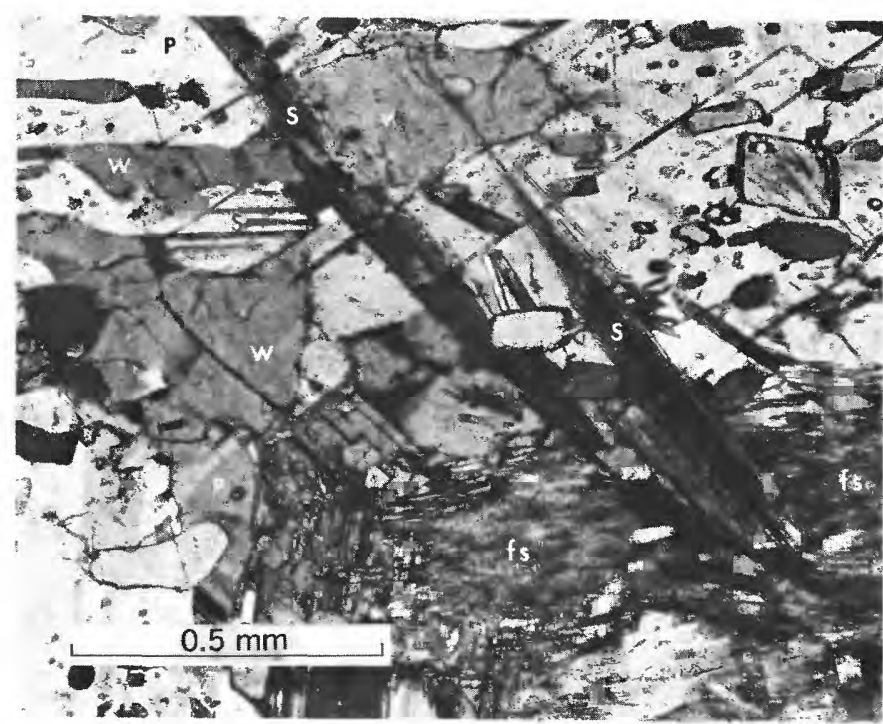

FiguRE 14.-Prismatic sillimanite (S) cuts wagnerite (W), plagioclase (P), and fibrolitic sillimanite (fs). Crossed polars.

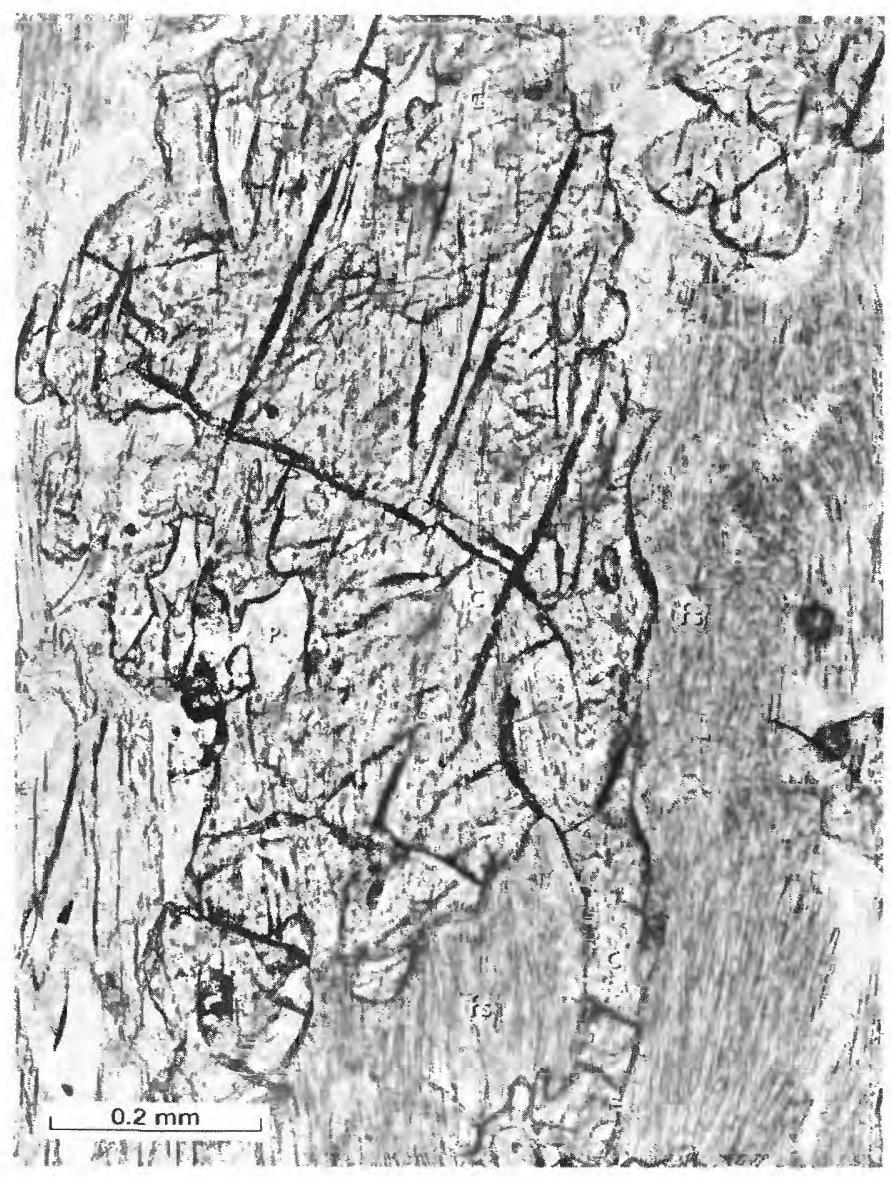

Figure 15.-Corundum (C) contains numerous tiny needles of sillimanite that are oriented parallel to the alinement of fibrolitic sillimanite (fs) in sillimanite-plagioclase gneiss. A small grain of plagioclase $(P)$ is partly enclosed by corundum. Plane-polarized light.

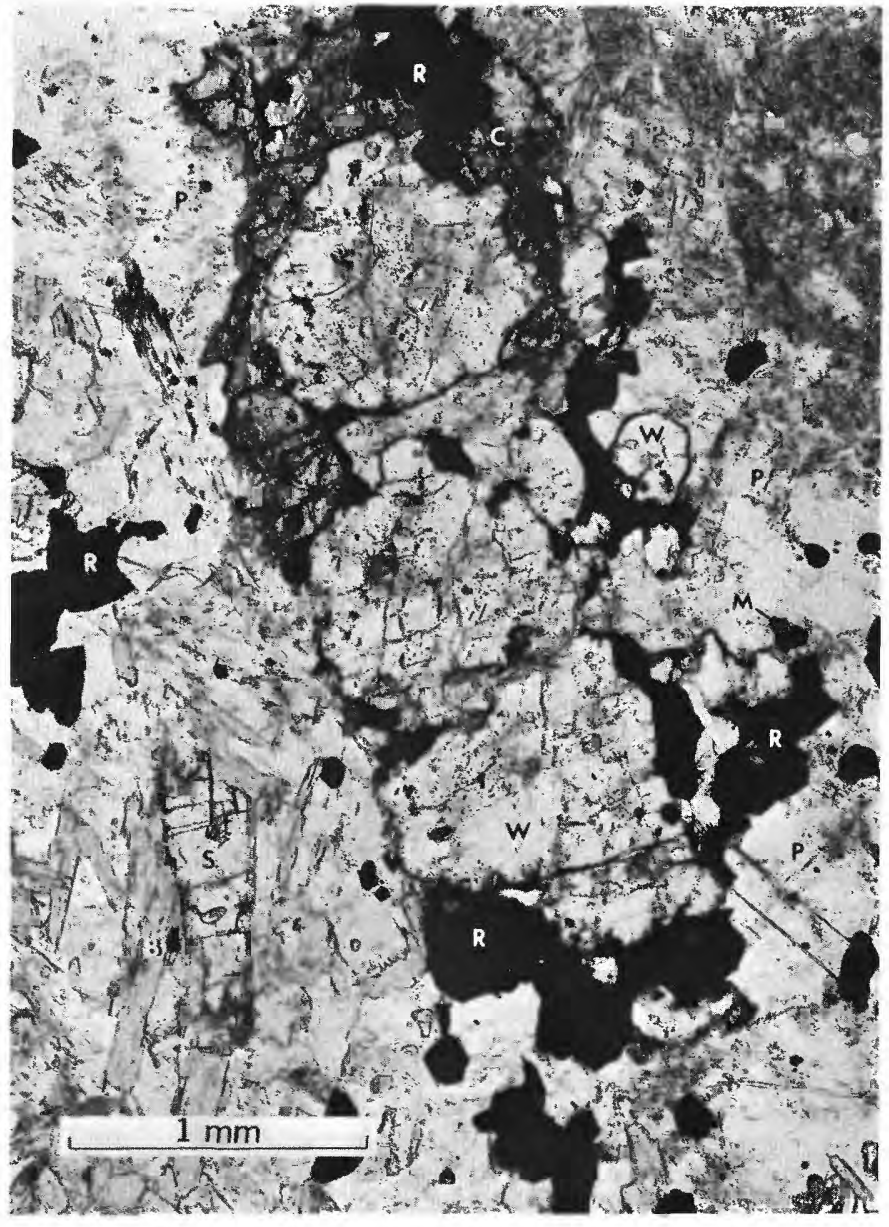

FIGURE 16.-Grain of wagnerite $(W)$ at top center is partly surrounded by a border of corundum (C). Numerous grains of rutile $(R)$ occur along the grain boundaries of wagnerite in this specimen. Other minerals are plagioclase $(P)$, biotite $(B)$, monazite $(M)$, and prismatic sillimanite (S). Plane-polarized light.

corundum grains are developed in aggregates of fibrolitic sillimanite and contain remnants of sillimanite needles that still retain the linear orientation of the fibrolitic aggregates (fig. 15). Rarely, wagnerite is surrounded in part by a corundum border (fig. 16).

Apatite and wagnerite have several textural relationships. Locally, prisms of apatite are surrounded by wagnerite (fig. 10); some aggregates of apatite grains are surrounded by a border of elongate wagnerite grains; a considerable proportion of the wagnerite grains are partially or completely rimmed by apatite. (See figs. 5, 8, 9.) Rims of apatite occur not only on exterior surfaces of wagnerite but also between the wagnerite and its poikiloblastic inclusions. Apatite rims have been observed between wagnerite and the following minerals: plagioclase, fibrolitic sillimanite, biotite, monazite, rutile, muscovite, and chlorite. The rims, therefore, do not appear to be a simple reaction rim of the type that occurs only between a specific pair of minerals. 
TABLE 5.-Chemical analyses of wagnerite

[Leaders (...) indicate not determined]

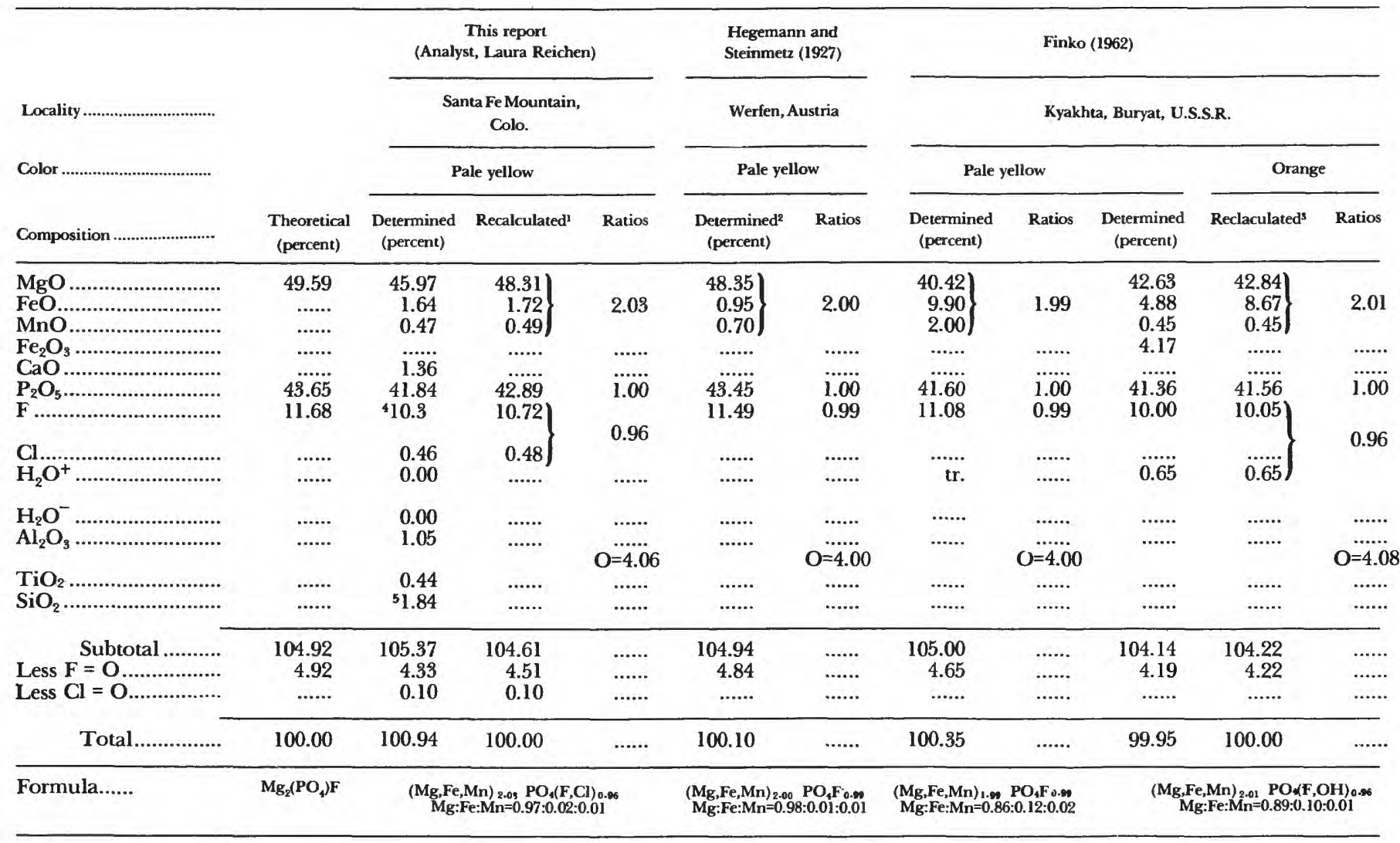

'Recalculated to 100 after deducting $\mathrm{CaO}$ as fluorapatite, $\mathrm{Al}_{2} \mathrm{O}_{3} \mathrm{TiO}_{2}$ and $\mathrm{SiO}_{2}$. ${ }^{2}$ Calculated to oxide values by the authors of this report from the original analysis. 'Recalculated to 100 by the authors of this report after first converting $\mathrm{Fe}_{2} \mathrm{O}_{3}$ to $\mathrm{FeO}$.

From the textural and mineralogic relations we make the following interpretations. The foliate fabric defined by wagnerite, plagioclase, fibrolitic sillimanite, and biotite apparently formed early during high-grade regional metamorphism. Except for prismatic sillimanite, corundum, some apatite, and minor chlorite and muscovite, the minerals of the sillimanite-plagioclase gneiss apparently crystallized at about the same time. Development of corundum and the large diversely oriented aggregates of prismatic sillimanite occurred later but probably during the same high-grade regional metamorphism. The larger grains of wagnerite may also belong to this later stage of crystallization. Chlorite and sericite probably formed still later under lower grade metamorphic conditions.

\section{CHEMISTRY}

Sample preparation for chemical analysis.-Because wagnerite occurs at the Santa Fe Mountain locality as a minor constituent of rutile-bearing gneiss, 1,000-1,500 g of the gneiss that showed the greatest visible concentra-
'Determined by specific ion electrode method by Johnnie Gardner, U.S. Geological Survey. ${ }^{3}$ Acid soluble $\mathrm{SiO}_{2}$

tions of wagnerite was used to prepare a sample large enough for chemical analysis. The sample of gneiss was broken into $1 / 4$-in. $(6 \mathrm{~mm})$ pieces, then it was ground to approximately 65 mesh $(0.208 \mathrm{~mm})$; the ground material was repeatedly washed with water and the fines decanted. After air drying, this material was sieved and the portion between $0.208 \mathrm{~mm}$ and $0.104 \mathrm{~mm}$ was retained; this fraction was then separated into light and heavy fractions, by use of bromoform (sp. gr., 2.86). The heavy fraction ( $>2.86$ ), which contained wagnerite, rutile, corundum, mica, sillimanite, and fluorapatite, was put through a Frantz isodynamic magnetic separator; splits were taken at 0.3 amps, 0.5 amps, and 1.3 amps. Wagnerite was concentrated in the $0.5 \mathrm{amp}$ fraction. Compound grains (wagnerite-rutile, wagnerite-sillimanite, wagneriteflourapatite, and silimanite-rutile) were removed by handpicking under the binocular microscope. Four and onehalf grams of visibly pure wagnerite were obtained for chemical analysis.

Methods of analysis. - The complete chemical analysis of wagnerite from Santa Fe Mountain, Colo. is given in table 5. The analytical methods used are as follows: 
1. $\mathrm{P}_{2} \mathrm{O}_{5}$. A portion of the sample was dissolved with nitric acid, and after a preliminary separation as ammonium phosphomolybdate, weighed as $\mathrm{Mg}_{2} \mathrm{P}_{2} \mathrm{O}_{7}$.

2. $\mathrm{F}, \mathrm{Cl}$. Both fluorine and chlorine were determined on the combined filtrates from two successive sodiumcarbonate fusions and water leaches of another fraction of the sample. Fluorine was weighed as $\mathrm{CaF}_{2}$ (Groves, 1951) and chlorine as AgCl. Because of the apparent low fluorine value ( 9.03 percent) obtained by this method, another fluorine determination by the specific-ion-electrode method was made; this value ( 10.3 percent) is the one reported in table 5 .

3. $\mathrm{FeO}$. The wagnerite sample was not noticeably affected by boiling for 15 minutes with 1:8 sulfuric acid, the usual method of attack for the determination of $\mathrm{FeO}$. However, the mineral was completely dissolved by heating for 24 hours at $65^{\circ} \mathrm{C}$ in $1: 15$ hydrochloric acid, to which a measured excess of standard potassium dichromate had been added to react with released ferrous iron.

4. $\mathrm{H}_{2} \mathrm{O}$. Total water was determined by the Penfield method.

5. $\mathrm{MgO}, \mathrm{CaO}, \mathrm{Al}_{2} \mathrm{O}_{3}, \mathrm{Fe}_{2} \mathrm{O}_{3}, \mathrm{TiO}_{2}, \mathrm{MnO}$, and insoluble. Nitric acid was used to dissolve the sample for these determinations. Repeated evaporations to dryness with the acid were necessary to completely dissolve the wagnerite. After a small insoluble fraction had been removed, the filtrate was evaporated to dryness so that the interfering phosphorus could be separated by a double extraction with sodium-carbonate fusion and water leach. Conventional methods then were used for the determination of the cations (Peck, 1964).

Chemical analysis and formula.-The analysis, after correction for impurities (fluorapatite, sillimanite, rutile, and quartz), led to the formula $(\mathrm{Mg}, \mathrm{Fe}, \mathrm{Mn})_{2.03} \mathrm{PO}_{4}$ $(\mathrm{F}, \mathrm{Cl})_{0.96}$, with $\mathrm{Mg}: \mathrm{Fe}: \mathrm{Mn}=0.97: 0.02: 0.01$, close to the empirical formula $\mathrm{Mg}_{2}\left(\mathrm{PO}_{4}\right) \mathrm{F}$. The presence of sillimanite, rutile, and quartz as impurities in the analyzed sample was confirmed by X-ray powder patterns taken of the insoluble residue obtained from digestion of part of the sample in nitric acid. Fluorapatite as a contaminant in the analyzed sample was suspected, but its presence could not readily be verified inasmuch as it probably was dissolved during analytical procedures. However, energy-dispersive microprobe analyses of five polished grains of carefully selected, pale-yellow, transparent fragments of wagnerite were made by Robert B. Finkelman of the U.S. Geological Survey. The results given in table 6 , showing an absence of $\mathrm{Ca}$ in the pure mineral, provide semiquantitative data that support the corrections made for impurities-including the subtraction of a fluorapatite phase-in recalculating the chemical analysis. (See table 5.)
TABLE 6. - Microprobe analysis of wagnerite from Santa Fe Mountain, Colorado (semiquantitative data) [Analyst, Robert B. Finkelman]

\begin{tabular}{|c|c|}
\hline Constituents ${ }^{1}$ & $\begin{array}{l}\text { Weight percent } \\
\text { (average of } 5 \text { grains) }\end{array}$ \\
\hline 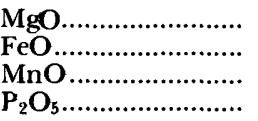 & $\begin{array}{r}\approx 50 \\
2 \\
\approx 1 \\
40\end{array}$ \\
\hline
\end{tabular}

ISi, Al, Ca, and $\mathrm{Ti}$ were below the limits of detection $(\approx 0.5$ percent). Fluorine could not be observed in this system.

The analysis of the Santa Fe Mountain wagnerite is compared in table 5 with other wagnerite analyses reported in the literature.

\section{X-RAY CRYSTALLOGRAPHY}

Single-crystal X-ray data.-Single-crystal X-ray study, made by the precession method, was carried out on a transparent, equant, pale-yellow fragment of wagnerite from Santa Fe Mountain, Colo. The precession photographs confirmed the monoclinic symmetry and space group $P 2_{1} / a$ (for $c<a$ ) and yielded the following preliminary crystallographic data: $a=11.94 \pm 0.01 \mathrm{~A}$, $b=12.68 \pm 0.01 \mathrm{~A}, c=9.65 \pm 0.01 \mathrm{~A}, \beta=108^{\circ} 10^{\prime} \pm 20^{\prime}$. The refined cell values, obtained by a least-squares refinement of the powder data (Appleman and Evans, 1973), are in excellent agreement with those reported by Coda, Guiseppetti, and Tadini (1967) for wagnerite from Werfen, Austria (table 7). The specific gravity calculated for wagnerite from the refined cell data is 3.16 , in good agreement with the measured value (3.13) obtained on a 500-mg sample by the pycnometer method.

Precession photographs of the Colorado wagnerite showed the presence of a strong monoclinic subcell with the $b$-axis halved $(6.335 \mathrm{~A})$; this subcell is in space group $I 2 / a$, with $Z=8$, which data confirm the observations of Coda, Guiseppetti, and Tadini (1967). The cell parameters of the subcell of the Colorado wagnerite are comparable with those reported in the literature for the triplite-group minerals-triplite, $(\mathrm{Mn}, \mathrm{Fe}, \mathrm{Mg}, \mathrm{Ca})_{2}\left(\mathrm{PO}_{4}\right)$ $(\mathrm{F}, \mathrm{OH})$ (Waldrop, 1969), and zwieselite, $(\mathrm{Fe}, \mathrm{Mn}, \mathrm{Mg}, \mathrm{Ca})_{2}$ $\left(\mathrm{PO}_{4}\right)(\mathrm{F}, \mathrm{OH})$ (C. T. Tennyson, in Strunz, 1970, p. 316).

$X$-ray powder data.-An X-ray powder diffraction pattern of the wagnerite from Santa Fe Mountain, Colo., was taken in a Debye-Scherrer powder camera fitted with a Wilson adapter (114.59 $\mathrm{mm}$ dia.) in $\mathrm{Fe} / \mathrm{Mn}$ radiation $(\lambda \mathrm{FeK} \alpha=1.9373 \mathrm{~A})$. Film measurements were corrected for expansion; the intensities of the observed lines were estimated visually by comparison with a calibrated intensity strip. Indexed X-ray powder-diffraction data for the Colorado wagnerite are cited in table 8 where they are compared with data for the calculated powder pattern of 
wagnerite from Werfen, Austria (based on the structural data of Coda and others, 1967); also, with data for wagnerite from Bamle, Norway (Henriques, 1957); from Kyakhta, U.S.S.R. (Finko, 1962); and from Dolni Bory, western Moravia, Czechoslovakia (Staněk, 1965).

Identity of ferroan wagnerite with magniotriplite.-Wagnerite, ferroan wagnerite, magniotriplite, triplite, and zwieselite are fluophosphates with the chemical formula $\mathrm{X}_{2}\left(\mathrm{PO}_{4}\right) \mathrm{F}$, where $\mathrm{X}=\mathrm{Mg}, \mathrm{Fe}^{+2}, \mathrm{Mn}^{+2}$, and (or) $\mathrm{Ca}$. In wagnerite, ferroan wagnerite, and magniotriplite, $\mathrm{Mg}$ is the dominant cation, generally with lesser amounts of $\mathrm{Fe}^{+2}, \mathrm{Mn}^{+2}$, and $\mathrm{Ca}$ substituting in part for $\mathrm{Mg}$; the dominant cation in triplite is $\mathrm{Mn}^{+2}$; in zwieselite the dominant cation is $\mathrm{Fe}^{+2}$. In these minerals, $(\mathrm{OH})^{-1}$ may substitute in part for $F^{-1}$. Strunz (1970) includes triplite, zwieselite, and wagnerite in the triplite series, a subgroup of the triplite-triploidite group. On the basis of recent crystallographic data (table 7), the minerals in the triplite series can be divided into two subgroups: (1), one containing magniotriplite, triplite, and zwieselite, with the $b$ axis $\approx 6.5 \mathrm{~A}$ and symmetry $I 2 / a$; (2), the other containing wagnerite, with the $b$ axis $\approx 12.5 \mathrm{~A}$ and symmetry $P 2_{1} / a$. Comparison of the structures of wagnerite (Coda and others, 1967) and triplite (Waldrop, 1969) indicates that the minerals are not isotypic; Waldrop (1969) noted that triplite and zwieselite show identical reflection intensities and, on this basis, suggested that they are isotypic.

Ferroan wagnerite from Hållsjöberget (Horrsjöberget), Sweden (Henriques, 1957)-formerly talktriplite of Igelström (1882)-and from pegmatites of the Albères massif, eastern Pyrenees, France (Fontan and others, 1970), and magniotriplite from Turkestan ridge, U.S.S.R. (Ginzburg and others, 1951), were identified as such solely on the basis of X-ray powder photography and chemical analysis. As far as is known, magniotriplite and so-called "ferroan wagnerite" have never been characterized crystallographically. Because of their high magnesium content, ferroan wagnerite from both of the localities and magniotriplite (type material) were examined by $\mathrm{X}$-ray powder diffraction and single-crystal techniques in order to establish their structural relation to wagnerite and (or) triplite.

$\mathrm{X}$-ray powder diffraction patterns of wagnerite, ferroan wagnerite, magniotriplite, and triplite are compared in figure 17. It is interesting to note that the patterns of the two ferroan wagnerites and the magniotriplite are identical and show a closer resemblance in spacings to the pattern of wagnerite than to that of triplite. The powder pattern of wagnerite, however, is visually distinguishable from the powder patterns of ferroan wagnerite and magniotriplite by the presence of a line at $5.66 \mathrm{~A}$ (table 8). This line also clearly showed up on films taken of wagnerite from Bamle, Norway (USNM C4151), Salzburg, Austria (USNM C4150), and Werfen, Austria (USNM

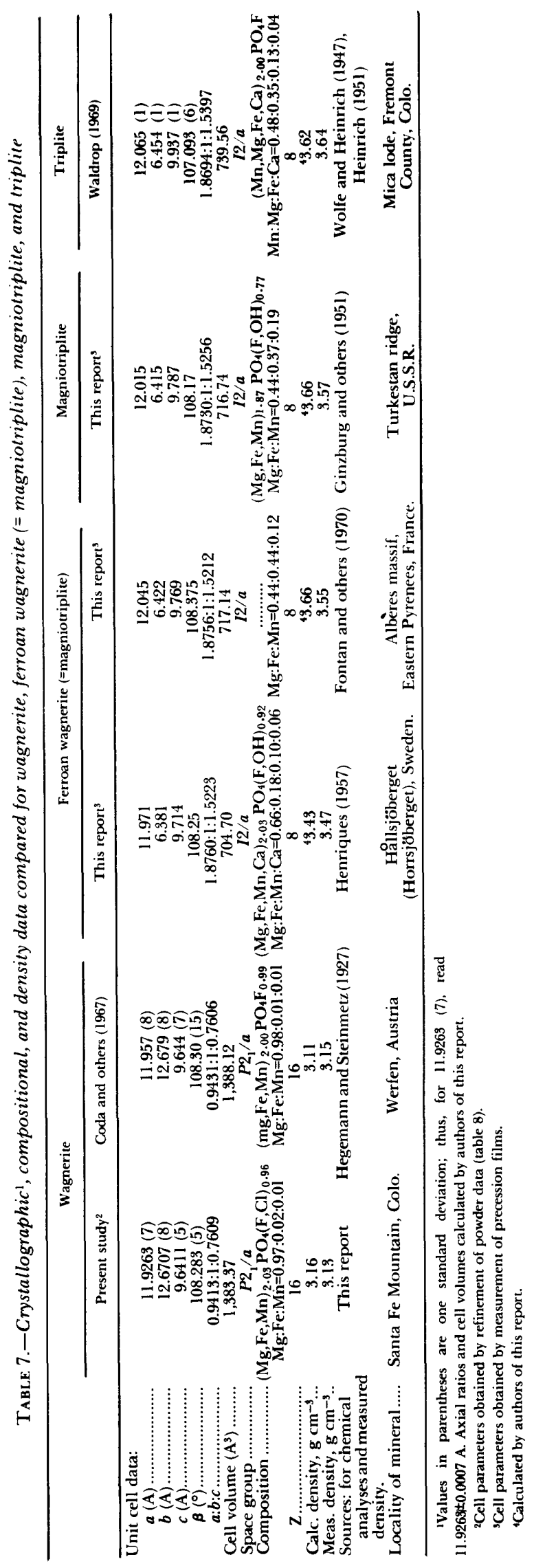


X-RAY CRYSTALLOGRAPHY

TABLE 8.-X-ray powder diffraction data for wagnerite, $\mathbf{M g}_{2}\left(\mathbf{P O}_{4}\right) \mathrm{F}$

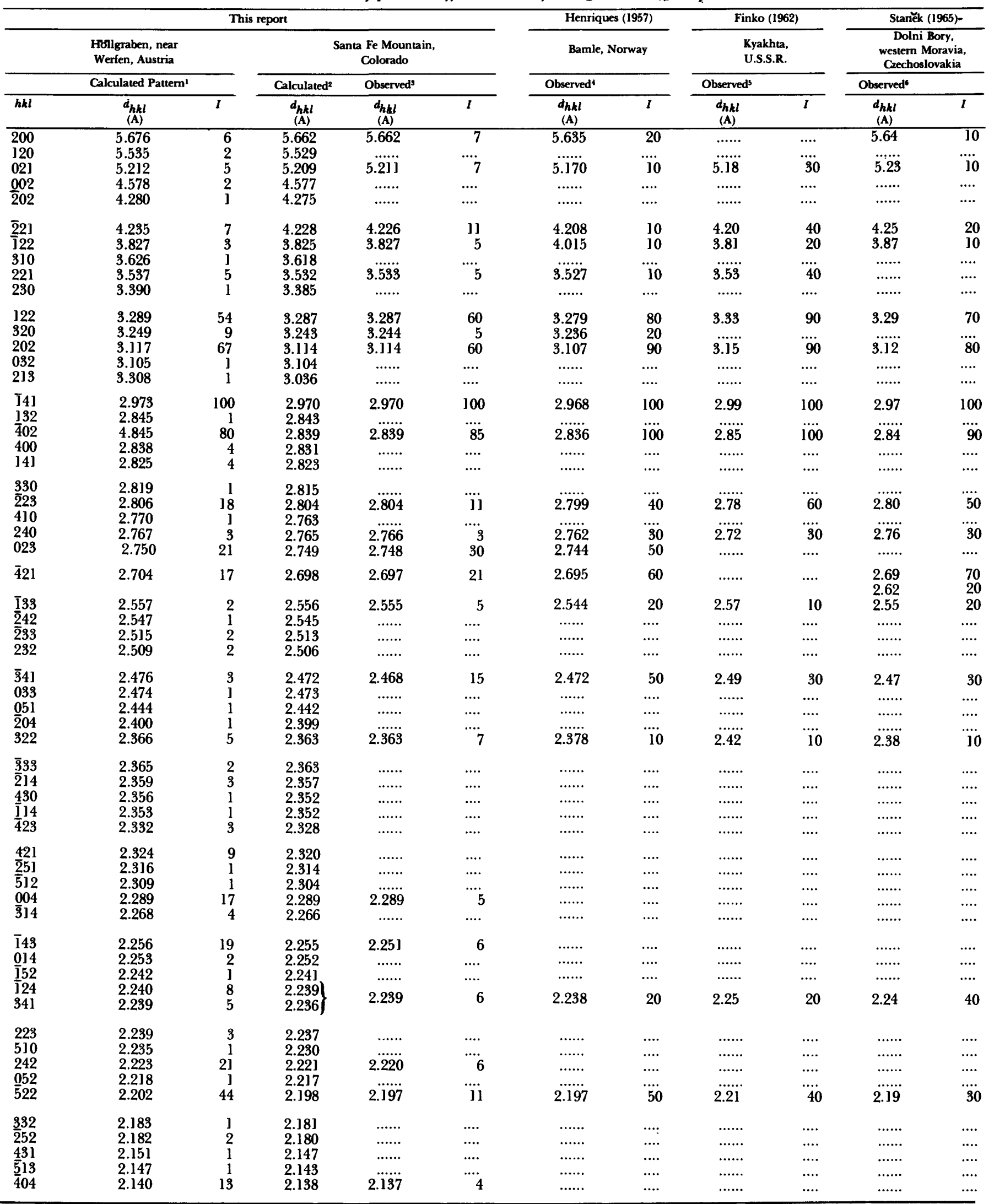


TABLE 8.-X-ray powder diffraction data for wagnerite, $\mathrm{Mg}_{2}\left(\mathrm{PO}_{4}\right) \mathrm{F}-\mathrm{Continued}$

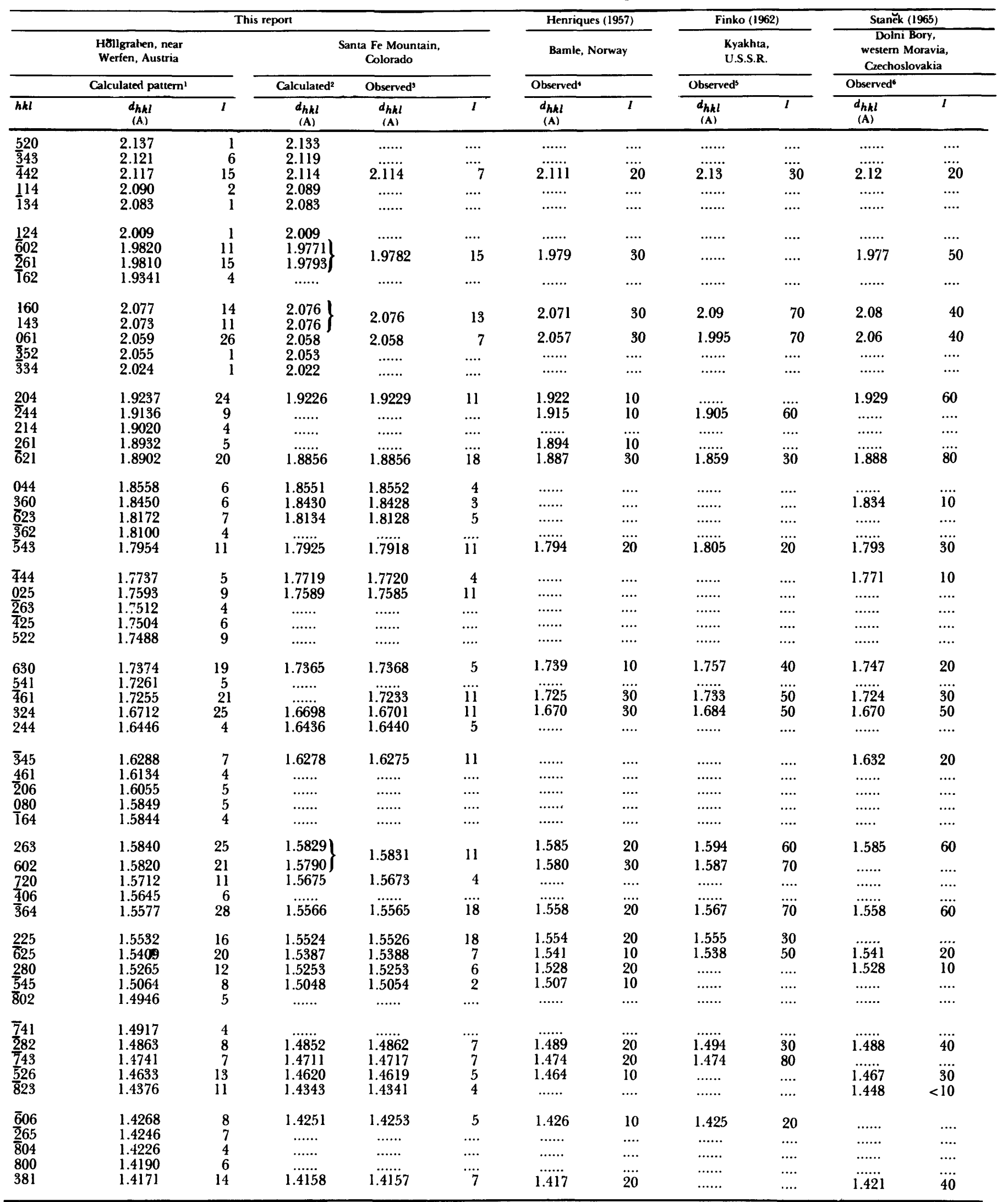

See footnotes at end of table, p. 19. 
TABLE 8.-X-ray powder diffraction data for wagnerite, $\mathrm{Mg}_{2}\left(\mathrm{PO}_{4}\right) \mathrm{F}-$ Continued

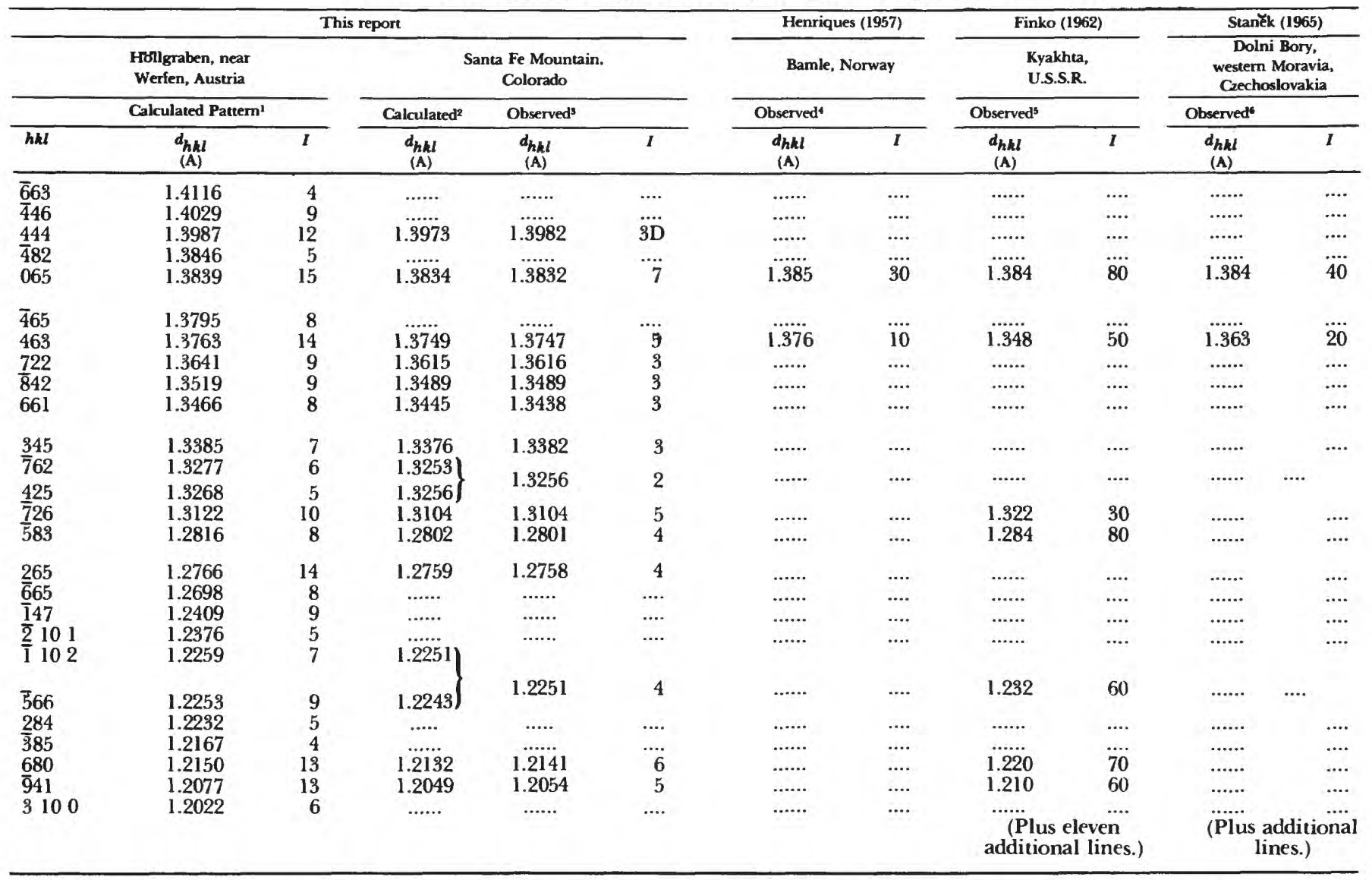

${ }^{2}$ Calculated from the crystal structure data of Coda, Guiseppetii, Tadini (1967) in space group $P 2_{1} / a: a=11.957 \mathrm{~A}, b=12.679 \mathrm{~A}, c=9.644 \mathrm{~A}, \beta=108^{\circ} 18^{\prime}$. All possible calculated dhel values listed for $d \geqslant 2.000 \mathrm{~A}$, for calculated intensities with $I \geq 1$; calculated $d_{h k l}$ values for $d<1.9999$ A given only for those with $l \geqslant 4$. Calculated integrated intensity data normalized to a maximum of 100 .

${ }^{2}$ Calculated from these unit-cell parameters obtained from least-squares refinement of the observed X-ray powder data with fixed indexing by use of the computer program of Appleman and Evans (1973): $a=11.926 \mathrm{~A}, b=12.671 \mathrm{~A}, c=9.641 \mathrm{~A}, \boldsymbol{\beta}=108^{\circ}$
17'. All possible calculated $d_{h k l}$ values listed for $d \geq 2.000 \mathrm{~A}$; calculated $d_{h k l}$ values for $d \leq 1.9999$ A listed only for those observed.

sCamera diameter, $114.59 \mathrm{~mm}$. Mn-filtered Fe radiation ( $\lambda$ FeK $\alpha=1.9373 \mathrm{~A}$ ). Wilsontype pattern. Film shrinkage negligible. Intensities estimated visually by direct comparison with a calibrated intensity film strip. $D=$ diffuse.

'Guinier camera. CuKa radiation.

'Sample 112, pale yellow. Camera diameter, $57.3 \mathrm{~mm}$. Unfiltered Fe radiation.

'Camera diameter, $114.6 \mathrm{~mm}$. Mn-filtered Fe radiation ( AFeK $\alpha=1.9373 \mathrm{~A}$ ).
R5306), when taken in iron radiation, but it was not present in any of the patterns taken of triplite from 18 different localities. The line at $5.66 \mathrm{~A}$ should be looked for in distinguishing patterns of wagnerite from those of the triplite series.

Preliminary crystallographic data for ferroan wagnerite and magniotriplite, based on precession photography, are given in table 7 where they are compared with data for wagnerite and triplite. Comparison of these data indicates that despite their high $\mathrm{Mg}$ content both the ferroan wagnerite from Hallsjöberget, Sweden, and the Albères massif, eastern Pyrenees, France, and the magniotriplite from the Turkestan ridge, U.S.S.R., are isostructural with triplite. Refined cell parameters and indexed powder data for both ferroan wagnerites and magniotriplite (Mrose, unpublished data) lead to the conclusion that the so-called "ferroan wagnerite" is actually magniotriplite, the $\mathrm{Mg}$ dominant member of the triplite series, and that, therefore, this material should not be referred to as ferroan wagnerite.

\section{ORIGIN}

The origin of the wagnerite at Santa Fe Mountain is linked inseparably with the origin of light-colored rutilebearing Precambrian gneisses in the east-central Front Range. Although the genetic history of these rutilebearing gneisses is admittedly debatable, we think that their field relations and their chemical and petrographic characteristics suggest very strongly that they were originally products of subaerial weathering (Marsh and Sheridan, 1976). According to this hypothesis, intense weathering of tuffs and flows of intermediate to basic composition occurred at several different times during the accumulation of a thick succession of volcanic and sedimentary rocks in Precambrian time. The resulting weathered products were bentonitic clays enriched in 

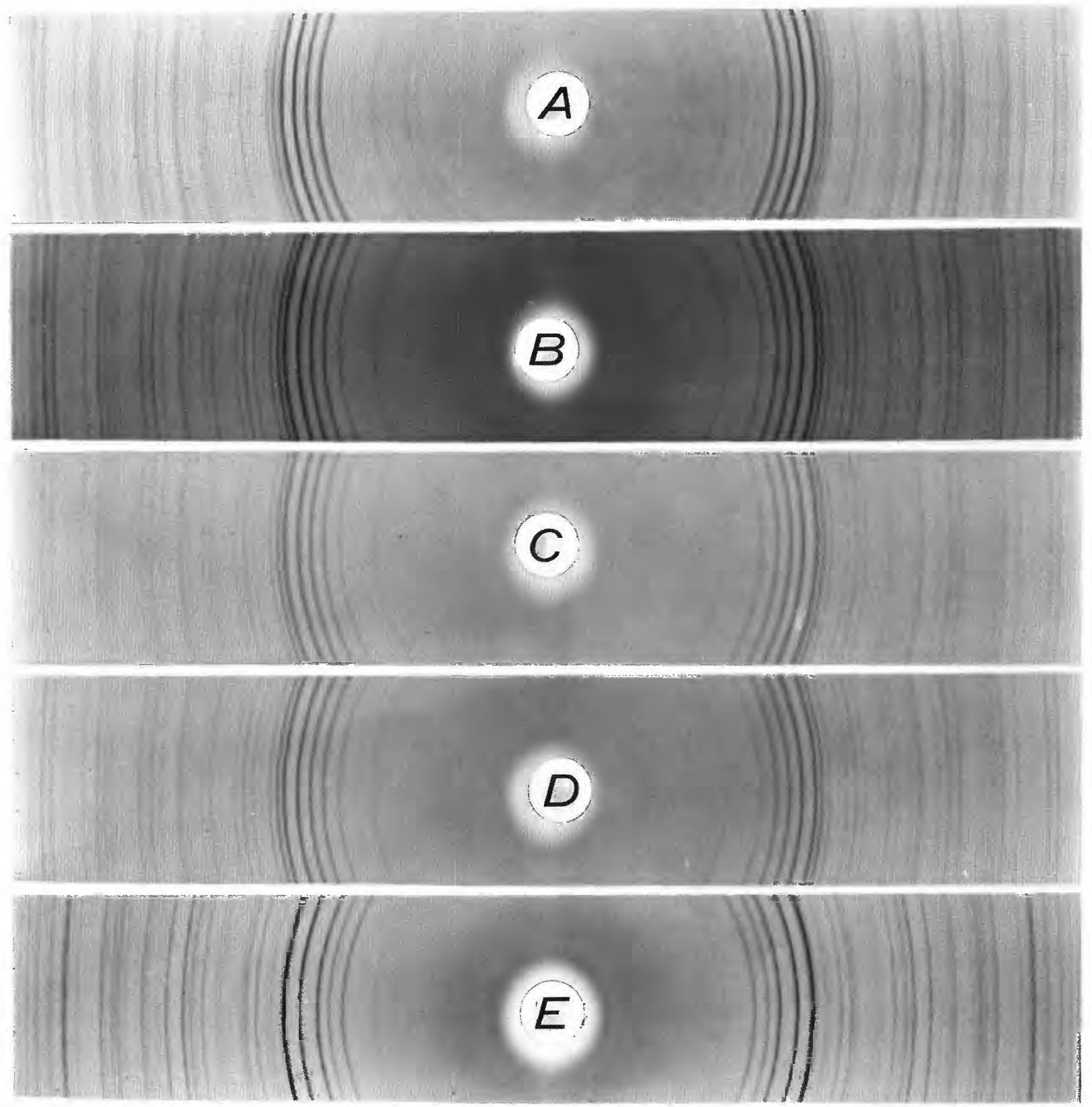

FIGURE 17.-X-ray powder photographs with Fe/Mn radiation (camera diameter: $114.59 \mathrm{~mm}$ ): $A$ ) wagnerite, Santa Fe Mountain, Colo.; B) ferroan wagnerite (formerly talktriplite of Igelstrom, 1882), Hållsjöberget (Horrsjöberget), Sweden; $C$ ) ferroan wagnerite, Albères massif, eastern Pyrenees, France; $D$ ) magniotriplite, Turkestan ridge, U.S.S.R. (Fersman Mineralogical Museum, Moscow; type material); E) triplite, Chatham, Conn. (USNM 93792; analyzed material).

titania (leucoxene), alumina (clay), and silica (clay and quartz) as compared to the unweathered volcanic rocks. Surface waters partly reworked these clays, distributing them as thin layers and lenses of somewhat variable composition. Various amounts of sedimentary materials were added to the clays and interlayered with them. Fluorine of probable volcanic source was adsorbed by the weathered products in varying amounts in different localities. After accumulation of additional layers of volcanic and sedimentary rocks, high-grade regional metamorphism took place throughout a long and complex period of Precambrian tectonism. Early in this period, the weathered products and their admixtures recrystallized to several varieties of rutile-bearing gneiss, some rich in sillimanite and quartz, some characterized by pale biotite and soda-rich plagioclase, and others gradational between these types. Wagnerite crystallized contemporaneously with fibrolitic sillimanite, biotite, and 
plagioclase in a local variant of the rutile-bearing gneiss. Foliation and lineation were formed in all the metamorphosed rocks during this early stage of crystallization. Somewhat later, this same long period of regional metamorphism culminated in conditions that promoted the growth of coarse crystals of some of the minerals. A certain amount of redistribution of fluorine, a type of fluorine metasomatism, occurred within the rutile-bearing layers. Coarse crystallization was enhanced by these volatiles. In some areas, such as the area described initially by Sheridan, Taylor, and Marsh (1968), topaz crystallized during concurrent growth of prismatic sillimanite. At the Santa Fe Mountain locality, large crystals of corundum, aggregates of prismatic sillimanite, and the larger grains of wagnerite were formed. During this same stage of crystallization, rims of apatite developed on wagnerite. Sericite and chlorite formed in a lower grade metamorphic environment, either during a retrograde stage of waning metamorphic intensity or perhaps during an even later event.

The origin of the principal types of Precambrian metamorphic rock in the east-central Front Range is, of course, fundamental to the genetic history of the wagnerite locality. Biotite gneiss, commonly sillimanitic, is one of the principal rocks in this region and was considered by Ball (in Spurr and Garrey, 1908, p. 44) to represent metamorphosed shaly sediments. Subsequent investigators have agreed with this conclusion and have considered the sillimanitic varieties as representing alumina-rich shales and the nonsillimanitic varieties as representing sandy shales or graywackes. The origin of feldspar-rich gneiss, the other principal metamorphic rock in this region, has been more problematical. Given various names, such as quartz monzonite gneiss and microcline gneiss, the feldspar-rich gneiss has been considered as an old intrusive igneous rock (Lovering and Goddard, 1950, p. 23) and as a metasedimentary rock (Moench and others, 1962, p. 38; Sheridan and others, 1967, p. 23). Hedge (1969, p. 12, 120-123) considered the feldspar-rich gneiss to be metamorphosed felsic volcanic rock because the gneiss is similar in chemical composition to acid volcanic rocks found in island arc association with basalts. Hornblende gneiss and amphibolite, also abundant in parts of this region, very likely were originally intermediate to basic tuffs and flows, and calc-silicate gneiss and impure marble were sedimentary rocks ranging in character from calcareous shale to argillaceous limestone. The early Precambrian history in this region, therefore, probably involved an accumulation of a thick, layered succession composed predominantly of volcanic and sedimentary rocks.

Thin layers and lenses of light-colored rutile-bearing gneiss occur at several stratigraphic levels in the Precambrian terrane of the east-central Front Range. The distribution, characteristics, and probable origin of these rutile-bearing gneisses have been discussed by Marsh and Sheridan (1976). Sillimanite-quartz gneiss, one of the principal varieties of rutile-bearing rock, has a simple but unusual mineral and chemical composition, containing very little else except quartz, sillimanite, and accessory rutile; it is chemically similar to many bentonitic clays. Rankama and Sahama (1950, p. 209, 563) have noted that clays produced by weathering are commonly low in calcium and high in aluminum and titanium. Serdyuchenko (1968) believed that metamorphic rocks containing kyanite, sillimanite, or corundum in many places in the world are metamorphosed kaolinite-bauxiteweathering crusts. Kyanite-quartz rock in India was considered by Dunn (1929, p. 248) to have been originally a surface decomposition of basalt to bauxitic clay. Espenshade and Potter (1960, p. 24-25) concluded that sediments containing clay or bauxite were the precursors of kyanite quartzite and sillimanite quartzite in some districts of the southeastern United States. Topax is present in notable amounts in some of the rutile-bearing rocks in the east-central Front Range, emphasizing the local importance of fluorine. It is likely that volcanic emanations provided this fluorine to the original weathered materials. In support of this hypothesis is the observation of Rankama and Sahama (1950, p. 764) that fluorine is added to the "exogenic cycle by volcanic processes" and that fluorine is strongly adsorbed in soils, bentonite, and bottom muds.

Although the details of the very early history of the rutile-bearing gneisses in the Front Range are matters involving considerable speculation, the present characteristics of these gneisses are the result of high-grade regional metamorphism. The rutile-bearing gneisses occur as persistent stratum-like layers and lenses in a thick succession of gneisses whose mineralogy, textures, and structural features all give evidence of folding and metamorphic recrystallization under high temperature and pressure. The regional character of the metamorphism, rather than a "contact" phenomena, is indicated by the absence of adjacent bodies of igneous rock. The high grade of metamorphism is indicated by the abundance of sillimanite in the light-colored gneisses and by the common presence of the pair sillimanite-microcline in pelitic gneiss layers of this region.

The texture and mineralogy of the wagnerite-bearing sillimanite-plagioclase gneiss indicate that all the minerals, except sericite and chlorite, are products of the regional high-grade metamorphism. The appearance of the rock, with its coarse prismatic sillimanite and the large grains of corundum diversely oriented in a foliated matrix of finer minerals, is similar in many respects to the porphyroblastic textures observed in other gneisses of this region. For example, calc-silicate gneiss and impure 
marble locally contain large porphyroblasts of garnet, epidote, and other minerals. Similarly, large randomly oriented porphyroblasts of andalusite occur in the mica schist unit of the nearby Ralston Buttes district (Sheridan and others, 1967, p. 8) $17 \mathrm{~km}$ northeast of the Santa Fe Mountain locality. We believe that such porphyroblasts developed in local sites where local pressure-temperature conditions and volatile concentrations favored the growth of coarse crystals late in the regional metamorphism.

Although bodies of pegmatite are present at the Santa Fe Mountain locality, they are not genetically related to the wagnerite. The pegmatites are of simple quartz-feldspar composition and contain no wagnerite.

The occurrence of wagnerite as a regional metamorphic mineral at Santa Fe Mountain is believed to be the direct result of the rather abnormal composition of the light-colored gneiss in which it is found. Apatite, not wagnerite, is the ubiquitous phosphate-bearing mineral in all the other gneisses. A calcium deficiency in the wagnerite-bearing gneiss is inferred from the high $\mathrm{Na}: \mathrm{Ca}$ ratio of the plagioclase and the paucity of other calciumbearing minerals. Although some apatite is present in the gneiss, calcium in the rock was apparently insufficient to accommodate all the available phosphate. The wagnerite further reflects the high $\mathrm{Mg}: \mathrm{Fe}$ ratio, consistent with the pale biotite that is rich in $\mathrm{Mg}$ and deficient in $\mathrm{Fe}$ as compared with the biotite in most other gneisses of this region.

\section{REFERENCES CITED}

Appleman, D. E., and Evans, H. T., Jr., 1973, Indexing and leastsquares refinement of powder diffraction data: U.S. Dept. Commerce, Natl. Tech. Inf. Service Pb2-1618, 67 p.

Cherkasov, Yu. A., 1955a, Dispersionny metod izmereniya pokazateley prelomleniya [Dispersion method for measuring the index of refraction]: Sbornik Nauch.-Tekh. Infor., Min. Geol. Okhrany Nedr., No. 1, p. 140-142 (in Russian).

1955b, Novyy variant immersionnogo metoda [A new variant of the immersion method]: Issledovanie mineral 'nogo syr'ia. Vses. Nauch-issled-ouatel 'skii Inst. Mineral 'nogo Syr'ia, p. 52-57 (in Russian).

1957, O primenenii "fokalnogo ekranirovaniya" pri izmereniyakh pokazateley prelomlenia immersionnym methodom [Application of "focal screening" to measurement of indices of refraction by the immersion method], in E. V. Rozhkova, ed., Sovremennye metody mineralogicheskogo issledovaniya gornykh porod, rud i mineralov [Modern methods of mineralogic investigations of rocks, ores, and minerals]: Moscow, Gosudar. Nauchno-Tekh. Izdat. Litera. Geol-Okrane Nedr., p. 184-207 (English translation in Internat. Geology Rev., v. 2., 1960, p. 218-235).

Coda, A., Guiseppetti, G., and Tadini, C., 1967, The crystal structure of wagnerite: Accad. Naz. Lincei Atti, Cl. Sci. Fis., Mat. e Nat. Mem., v. 43, p. 212-224.

Deer, W. A., Howie, R. A., and Zussman, J., 1962, Ortho- and ring silicates, v. 1 of Rock-forming minerals: New York, John Wiley and Sons, Inc., $333 \mathrm{p}$.

Doelter, C., 1918, Wagnerit, Magnesium-Fluoro-orthophosphat, in Doelter, C., Handbuch der Mineralchemie: Dresden und Leipzig, Verlag von Theodor Steinkopff, v. 3, no. 1, p. 318-320.
Dunn, J. A., 1929, The aluminous refractory minerals-kyanite, sillimanite, and corundum in northern India: Geol. Survey India Mem. 52, pt. 2, p. 145-274, and indexes.

Espenshade, G. H., and Potter, D. B., 1960, Kyanite, sillimanite, and andalusite deposits of the southeastern States: U.S. Geol. Survey Prof. Paper 336, 121 p.

Fahey, J. J., 1961, A method for determining the specific gravity of sand and ground rock or minerals: U.S. Geol. Survey Prof. Paper 424-C, p. C372-C373.

Finko, V. I., 1962, Pervaya nakhodka vagnerita v SSSR [The first specimen of wagnerite from the U.S.S.R.]: Akad. Nauk SSSR Doklady, v. 143, no. 6, p. 1424-1427 (in Russian).

Fontan, F., Beziat, P.-V., Lacomme, A., and Subra, A., 1970, Sur quelques phosphates des pegmatites du massif des Albères, Pyrénées-Orientales: Soc. Française Minéralogie et Cristallographie Bull., v. 93, p. 583-584.

Gable, D. J., and Sims, P. K., 1969, Geology and regional metamorphism of some high-grade cordierite gneisses, Front Range, Colorado: Geol. Soc. America Spec. Paper 128, 87 p.

Ginzburg, A. I., Kruglova, N. A., and Moleva, V. A., 1951, Magniotriplit-novyy mineral iz gruppy triplita [Magniotriplite-a new mineral of the triplite group]: Akad. Nauk SSSR Doklady, v. 76, no. 1, p. 97-100 (in Russian).

Groves, A. W., 1951, Silicate analysis [2d ed.]: London, Allen and Unwin, $336 \mathrm{p}$.

Hedge, C. E., 1969, A petrogenetic and geochronologic study of migmatites and pegmatites in the central Front Range: Colorado School Mines unpub. Ph. D. thesis, $158 \mathrm{p}$.

Hegemann, F., and Steinmetz, H., 1927, Die Mineralgange von Werfen im Salzkammergut: Centralblatt Mineralogie, Geologie und Paläontologie, Pt. A, p. 45-56.

Heinrich, E. W., 1951, Mineralogy of triplite: Am. Mineralogist, v. 36 , nos. 3-4, p. 256-271.

Henriques, Ake, 1957, An iron-rich wagnerite, formerly named talktriplite, Hållsjöberget (Horrsjöberget), Sweden: Arkiv Mineralogi och Geologi, v. 2, no. 6, p. 149-153.

Igelström, L. J., 1882, Nya mineral från Vermland, 2:o Talktriplit, ett nytt mineral från Horrsjöberg i Wermland: Svenska Vetenskapsakademien, Stockholm, Handl. Öfv., v. 39, p. 86-91.

Lovering, T. S., and Goddard, E. N., 1950, Geology and ore deposits of the Front Range, Colorado: U.S. Geol. Survey Prof. Paper 223, $319 \mathrm{p}$.

Marsh, S. P., and Sheridan, D. M., 1976, Rutile in Precambrian sillimanite-quartz gneiss and related rocks, east-central Front Range, Colorado: U.S. Geol. Survey Prof. Paper 959-G.

Michel-Lévy, A., and Lacroix, Alf., 1888, Les Minéraux des Roches: Paris, Libr. Polytech., 334 p.

Moench, R. H., Harrison, J. E., and Sims, P. K., 1962, Precambrian folding in the Idaho Springs-Central City area, Front Range, Colorado: Geol. Soc. America Bull., v. 73, no. 1, p. 35-58.

Peck, L. C., 1964, Systematic analysis of silicates: U.S. Geol. Survey Bull. 1170, 89 p.

Rankama, K. K., and Sahama, T. G., 1950, Geochemistry: Chicago Univ. Press, 912 p.

Serdyuchenko, D. P., 1968, Metamorphosed weathering crusts of the Precambrian, their metallogenic and petrographic features in Proceedings of section 4, Geology of Pre-Cambrian: Internat. Geol. Cong., Rept. 23d Sess., Czechoslovakia, 1968, v. 4, p. 37-42.

Sheridan, D. M., Marsh, S. P., Mrose, M. E., and Taylor, R. B., 1971, Wagnerite from Santa Fe Mountain, Colorado: a new occurrence [abs.]: Canadian Mineralogist, v. 10, part 5, p. 919.

Sheridan, D. M., Maxwell, C. H., and Albee, A. L., 1967, Geology and uranium deposits of the Ralston Buttes district, Jefferson County, Colorado, with sections on Paleozoic and younger sedimentary rocks by Richard Van Horn: U.S. Geol. Survey Prof. Paper 520, 121 p. 
Sheridan, D. M., Taylor, R. B., and Marsh, S. P., 1968, Rutile and topaz in Precambrian gneiss, Jefferson and Clear Creek Counties, Colorado: U.S. Geol. Survey Circ. 567, 7 p.

Smith, J. R., 1960, Optical properties of low-temperature plagioclase, appendix 3, in Hess, H. H., Stillwater igneous complex, Montana: Geol. Soc. America Mem. 80, p. 191-219, incl. diagrams and tables, pl. 12.

Spurr, J. E., and Garrey, G. H., 1908, Economic geology of the Georgetown quadrangle (together with the Empire district), Colorado, with general geology, by S. H. Ball: U.S. Geol. Survey Prof. Paper $63,422 \mathrm{p}$.

Stanĕk, Josef, 1965, První výskyt wagneritu v Československu [The first occurrence of wagnerite from Czechoslovakia]: Brno, Moravské Muzeum, Cas. Moravskeho Musea v Brné, v. 50, p. 67-70 (in Slovak).
Strunz, H., 1970, Mineralogische Tabellen: Akad. Verlagsgesellschaft Geest \& Portig K.-G., Leipzig, 621 p.

Waldrop, L., 1969, The crystal structure of triplite, $(\mathrm{Mn}, \mathrm{Fe})_{2} \mathrm{FPO}_{4}$ : Zeitschr. Kristallographie, v. 130, p. 1-14.

Wilcox, R. E., 1959, Use of the spindle stage for determination of principal indices of refraction of crystal fragments: Am. Mineralogist, v. 44, nos. 11-12, p. 1272-1293.

Winchell, A. N., and Winchell, Horace, 1951, Description of minerals, Pt. 2 of Elements of optical mineralogy-an introduction to microscopic petrography [4th ed.]: New York, John Wiley \& Sons, $551 \mathrm{p}$.

Wolfe, C. W., and Heinrich, E. W., 1947, Triplite crystals from Colorado: Am. Mineralogist, v. 32, nos. 9-10, p. 518-526. 